\title{
Microzooplankton grazing impact on the phytoplankton community at a coastal upwelling station off northern Baja California, Mexico
}

\section{Impacto del pastoreo del microzooplancton sobre la comunidad fitoplanctónica en una estación de surgencia costera localizada en la región norte de Baja California, México}

\author{
Lorena Linacre ${ }^{*}$, J Rubén Lara-Lara ${ }^{1}$, Uriel Mirabal-Gómez ${ }^{1}$, Reginaldo Durazo², \\ Carmen Bazán-Guzmán ${ }^{1}$ \\ ${ }^{1}$ Departamento de Oceanografía Biológica, División de Oceanología, Centro de Investigación Científica y de \\ Educación Superior de Ensenada (CICESE), Carretera Tijuana-Ensenada, no. 3918, Zona Playitas, CP 22860, \\ Ensenada, Baja California, México. \\ ${ }^{2}$ Facultad de Ciencias Marinas, Universidad Autónoma de Baja California, Carretera Tijuana-Ensenada, \\ no. 3917, Zona Playitas, CP 22860, Ensenada, Baja California, México. \\ * Corresponding author. E-mail: 1linacre@cicese.mx
}

\begin{abstract}
Experiments were carried out at a coastal upwelling site (ENSENADA station) off northern Baja California (México) during autumn 2015 (OCT-15) and spring 2016 (APR-16) to estimate phytoplankton daily growth $\left(\mu_{\mathrm{o}}\right)$ and mortality $(\mathrm{m})$ rates and to assess microzooplankton grazing impact $\left(m: \mu_{\mathrm{o}}\right)$ on the phytoplankton community and specific autotrophic groups. In accordance with regional seasonality and under an environmental warming scenario due to the El Niño 2015-2016 event, significant differences in both hydrographic conditions and the growth-mortality dynamics of the phytoplankton community were observed between the 2 study periods. The $\mu_{\mathrm{o}}$ and $m$ estimates were, respectively, $0.120 \pm 0.012 \mathrm{~d}^{-1}$ and $1.145 \pm 0.049 \mathrm{~d}^{-1}$ for OCT-15 and $1.186 \pm 0.002 \mathrm{~d}^{-1}$ and $0.409 \pm 0.086 \mathrm{~d}^{-1}$ for APR-16. The results of this study suggest that the effects of the anomalous warming on the phytoplankton community were more evident in OCT-15. During that period, growth of the larger autotrophic components (diatoms) was severely controlled by the environmental limitation of nutrients caused by the sinking of the thermocline that resulted from the entrance of warm water to the region. Furthermore, microzooplankton exerted active grazing pressure on phytoplankton biomass $\left(72 \%\right.$ of chlorophyll $a[$ Chla] $)$ and primary production $\left(\mathrm{PP}=0.20 \mu \mathrm{g}\right.$ Chla $\left.\cdot \mathrm{L}^{-1} \cdot \mathrm{d}^{-1}\right)$, with grazing impact $>100 \%$ of PP. In APR-16, when the ecosystem apparently started returning to the spring conditions, a high value for PP $\left(3.73 \mu \mathrm{g} C h l a \cdot \mathrm{L}^{-1} \cdot \mathrm{d}^{-1}\right)$ was estimated, with only one third of it being consumed by microzooplankton (34\% of PP). The results of this research evidence the high dynamism of multivorous food webs coupled to the seasonal and interannual variability of coastal upwelling systems.
\end{abstract}

Key words: phytoplankton growth rate, microzooplankton grazing, El Niño 2015-2016, ENSENADA station, Baja California

RESUMEN. En un sitio de surgencia costera (estación ENSENADA) frente a la región norte de Baja California (México) se realizaron experimentos durante el otoño de 2015 (OCT-15) y la primavera de 2016 (ABR-16) para estimar las tasas diarias de crecimiento $\left(\mu_{\mathrm{o}}\right)$ y mortalidad $(m)$ del fitoplancton, que permitieron evaluar el impacto $\left(m: \mu_{\mathrm{o}}\right)$ que genera el pastoreo diario del microzooplancton sobre la comunidad de fitoplancton y grupos autótrofos específicos. Acorde con la estacionalidad de la región y bajo el escenario de un calentamiento ambiental debido al evento El Niño 2015-2016, se observaron notables diferencias en las condiciones hidrográficas y en la dinámica de crecimiento y mortalidad de la comunidad de fitoplancton entre los 2 periodos de estudio. Las estimaciones de $\mu_{\mathrm{o}} \mathrm{y} m$ fueron, respectivamente, $0.120 \pm 0.012 \mathrm{~d}^{-1}$ y $1.145 \pm 0.049 \mathrm{~d}^{-1}$ para OCT-15 y $1.186 \pm 0.002 \mathrm{~d}^{-1}$ y $0.409 \pm 0.086 \mathrm{~d}^{-1}$ para ABR-16. Los resultados de este estudio sugieren que los efectos del calentamiento anómalo sobre la comunidad del fitoplancton fueron más evidentes durante OCT-15. En ese periodo, los componentes autotróficos más grandes (diatomeas) estuvieron fuertemente restringidos en su crecimiento, posiblemente por una limitación ambiental de nutrientes ocasionada por el hundimiento de la termoclina debido al mayor aporte de agua cálida. Además, se estimó un activo consumo del microzooplancton sobre la biomasa $\left(72 \%\right.$ de clorofila $a$ [Chla]) y producción primaria $\left(\mathrm{PP}=0.20 \mu \mathrm{g} \mathrm{Chla} \cdot \mathrm{L}^{-1} \cdot \mathrm{d}^{-1}\right)$ de fitoplancton ( $>100 \%$ de la PP). Para ABR-16, cuando aparentemente se empezaron a manifestar las condiciones propias de primavera en el ecosistema, se estimó una PP alta $\left(3.73 \mu \mathrm{g} C h l a \cdot \mathrm{L}^{-1} \cdot \mathrm{d}^{-1}\right)$ y sólo una tercera parte de ésta fue consumida por el microzooplancton $(34 \%$ de la PP). Los resultados de esta investigación revelan el alto dinamismo de las tramas tróficas multívoras acoplado a la variabilidad estacional e interanual de los sistemas de surgencia costera.

Palabras clave: tasa de crecimiento de fitoplancton, pastoreo del microzooplancton, El Niño 2015-2016, estación ENSENADA, Baja California. 


\section{INTRODUCTION}

Marine microzooplankton (protists $<200 \mu \mathrm{m}$ in size, represented by heterotrophic nanoflagellates, ciliates, and heterotrophic and mixotrophic dinoflagellates), as components of a microbial food web, play a significant role in different ecosystems by consuming a wide range of prey (from pico- to microplankton cells). This component represents an important trophic pathway for organic matter (carbon) and energy to be transferred from primary producers to higher trophic levels. Thus, the trophic function, structure (size and composition), and relative abundance of microzooplankton determine the amount of carbon available for higher trophic levels and the amount that can be "pumped" to the deep ocean (Chisholm 2000).

Some studies have shown that many productive and seasonal ecosystems, such as coastal upwelling systems, are characterized by multivorous food webs. In these systems, not only organisms belonging to the typical herbivorous trophic pathway (diatoms, copepods, and pelagic fish) but also microbial trophic components make up a complex trophic structure that gives this type of coastal ecosystems the ability to recycle carbon efficiently within the pelagic zone (Vargas et al. 2007, Linacre et al. 2010a, Teixeira et al. 2011, 2012).

Microzooplankton grazing impact has been measured on a global scale based on the widely used dilution method of Landry and Hasset (1982). On average, microzooplankton consumes $67 \%$ of phytoplankton daily production (Calbet and Landry 2004). In particular, significant differences in microzooplankton grazing and, consequently, carbon flow have been reported for several coastal regions. Seasonal dynamics in the composition and size of consumers, coupled with changes in their phytoplanktonic prey, leads to temporal variability in carbon and energy flows to higher trophic levels (Calbet et al. 2008, Texeira et al. 2011, Linacre et al. 2012).

Given the large significance of the trophic transfer of primary production through microbial pathways in a coastal ecosystem, the purpose of this study is to evaluate the daily microzooplankton grazing impact on phytoplankton community in a coastal upwelling system within the California Current System (CCS). Two strikingly contrasting seasons were considered, autumn 2015 and spring 2016, in an environment that has been subjected to intense anomalous interannual warming events in recent years ("The warm Blob" 2013-2015 and El Niño 2015-2016; Cavole et al. 2016, Jacox et al. 2016). These events changed the physicochemical structure of the water column and caused significant biological effects in the CCS (McClatchie et al. 2016, Zaba and Rudnick 2016, Gomez-Ocampo et al. 2017). In this context of anomalous warming, changes in growth and mortality dynamics of the phytoplankton community are expected. Under this environmental scenario, the present study estimated the phytoplankton growth and grazing rates in October

\section{INTRODUCCIÓN}

El microzooplancton marino (protistas $<200 \mu \mathrm{m}$ de tamaño representados por nanoflagelados heterotróficos, ciliados y dinoflagelados mixotróficos y heterotróficos), como componente de una trama trófica microbiana, juega un papel significativo en diversos ecosistemas debido a que consume una amplia gama de presas (desde pico- hasta microplancton). Así, este componente representa una importante vía de transferencia de materia orgánica (carbono) y energía desde los productores primarios hacia niveles tróficos superiores. Por tanto, la función de transferencia trófica, la estructura (tamaño y composición) y la abundancia relativa del microzooplancton determinan en gran medida la cantidad de carbono disponible para ser fijado en niveles tróficos superiores y que puede ser "bombeado" hacia el océano interior (Chisholm 2000).

Algunos estudios han demostrado que muchos ecosistemas productivos y estacionales, como los sistemas de surgencia costera, se caracterizan por presentar tramas tróficas multívoras. En estos ambientes, no sólo organismos de la clásica vía trófica herbívora (diatomeas, copépodos y peces pelágicos) sino también los componentes tróficos microbianos conforman una estructura trófica compleja que le confieren a este tipo de ecosistemas costeros la habilidad de reciclar carbono eficientemente dentro de la zona pelágica (Vargas et al. 2007, Linacre et al. 2010a, Teixeira et al. 2011, 2012).

A nivel global, se han realizado mediciones del impacto del pastoreo del microzooplancton con base en el ampliamente usado método de dilución de Landry y Hasset (1982), con el cual se ha estimado un consumo promedio del $67 \%$ de la producción primaria diaria de fitoplancton (Calbet y Landry 2004). Particularmente, se han reportado importantes diferencias en el pastoreo del microzooplancton y, consecuentemente, en el flujo del carbono en diversas regiones costeras. Lo anterior es debido a que la dinámica estacional en la composición y tamaño de los consumidores se encuentra acoplada a la de sus presas fitoplanctónicas, lo cual genera una variabilidad temporal en la vía de transferencia de carbono y energía hacia los niveles tróficos superiores (Calbet et al. 2008, Teixeira et al. 2011, Linacre et al. 2012).

Dada la gran significancia que tiene el proceso biológico de transferencia trófica de la producción primaria por vías microbianas dentro un ecosistema costero, el presente estudio tiene como objetivo la evaluación del impacto que genera el pastoreo diario del microzooplancton sobre la comunidad de fitoplancton en un sistema de surgencia costera del Sistema de la Corriente de California (SCC). Se consideran 2 épocas estacionalmente contrastantes, el otoño de 2015 y la primavera de 2016, en un ambiente que en los últimos años ha estado sujeto a intensos eventos interanuales de calentamiento anómalo ("The warm Blob" 2013-2015 y El Niño 2015-2016; Cavole et al. 2016, Jacox et al. 2016). Estos eventos modificaron la estructura físicoquímica de 
2015 and April 2016. In addition, total phytoplankton biomass (chlorophyll $a$ ), autotrophic components (pigment composition and taxonomic groups by microscopy), and potential microzooplankton consumers were determined for each season. These observations were carried out at the ENSENADA station, a coastal site that has been described as representative of the physicochemical conditions off northern Baja California, Mexico, and susceptible to the temporal variability (seasonal and interannual) that occurs in coastal areas $(<50 \mathrm{~km})$ (Linacre et al. 2010b).

\section{MATERIALS AND METHODS}

\section{Seawater sampling}

The ENSENADA sampling station $\left(31.66^{\circ} \mathrm{N}, 116.70^{\circ} \mathrm{W}\right)$ is located in the northern region of the Baja California Peninsula (Fig.1). To study phytoplankton growth and mortality dynamics, experiments were carried out at this coastal site during 2 oceanographic cruises, one in October 2015 (OCT-15) and the other in April 2016 (APR-16). Continuous measurements of pressure, temperature, conductivity, dissolved oxygen, and fluorescence were recorded down to $\sim 100 \mathrm{~m}$ depth using a CTD rosette. Seawater was collected using 5-L Niskin bottles at 7 optical levels within the euphotic zone $(100 \%, 50 \%, 30 \%, 20 \%, 10 \%, 1 \%$, and $0.1 \%$ of surface photosynthetically active radiation $[\mathrm{PAR}], \% \mathrm{E}_{\mathrm{o}}$ ) and at the depth level of the deep fluorescence maximum (DFM). For chorophyll a (Chla) (3 replicates) and accessory pigment analyses, $1 \mathrm{~L}$ of seawater was collected and filtered through a $25-\mathrm{mm} \mathrm{GF} / \mathrm{F}$ filter, which was immediately frozen in liquid nitrogen.

\section{Routine seawater analyses}

At the laboratory, Chla concentrations were determined by the fluorometric non-acidification method described by Welshmeyer (1994) using a Turner Designs Trilogy fluorometer. Accessory pigment concentrations were determined by high-performance liquid chromatography (HPLC) following the techniques described in Almazán-Becerril and GarcíaMendoza (2008). Taxonomic assignments were based on known pigment compositions associated with phytoplankton groups previously reported for the study site (Linacre et al. 2012): divinyl chlorophyll $a$ (DV-Chla) is found exclusively in Prochlorococcus populations; zeaxanthin (Zea) is mostly assigned to cyanobacteria; fucoxanthin (Fuco) is mainly associated with diatoms; and peridinin (Perid) is found only in some dinoflagellate groups. Concentrations of 19'hexanoyloxyfucoxanthin (Hex-Fuco) and 19'-butanoyloxyfucoxanthin (But-Fuco) are mainly found in some nanoflagellate groups, such as prymnesiophytes and pelagophytes, respectively. Nanoflagellate green algae usually contain chlorophyll $b(C h l b)$, including some types of prasinophytes, whose characteristic pigment is prasinoxanthin (Pras). la columna de agua y ocasionaron importantes efectos biológicos dentro del SCC (McClatchie et al. 2016, Zaba y Rudnick 2016, Gomez-Ocampo et al. 2017). En este contexto de calentamiento anómalo, la comunidad fitoplanctónica está posiblemente sujeta a cambios en su dinámica de crecimiento y mortalidad debido al pastoreo del microzooplanton. Bajo este escenario ambiental, en el presente estudio se estimaron las tasas de crecimiento y de pastoreo de fitoplancton en octubre de 2015 y en abril de 2016. Para cada época se estimó, además, la biomasa total de la comunidad fitoplanctónica (clorofila $a$ ), sus componentes autotróficos (composición pigmentaria y grupos por microscopía) y sus potenciales grupos de predadores microzooplanctónicos. Las observaciones se realizaron en un sitio costero (estación ENSENADA) que ha sido descrito como representativo de las condiciones químico-físicas de la parte norte de Baja California, México, y susceptible a las variaciones temporales (estacionales e interanuales) que ocurren en la costa $(<50 \mathrm{~km})$ (Linacre et al. 2010b).

\section{MATERIALES Y MÉTODOS}

\section{Colecta de agua de mar}

La estación de muestreo ENSENADA $\left(31.66^{\circ} \mathrm{N}\right.$, $116.7^{\circ} \mathrm{W}$ ) está localizada en la región norte de la península de Baja California (Fig.1). En dicha estación se realizaron experimentos para investigar la dinámica del crecimiento y mortalidad de la comunidad de fitoplancton durante 2 campañas oceanográficas, una en octubre de 2015 (OCT-15) y la otra en abril de 2016 (ABR-16). Se realizaron lances de CTD/roseta hasta $\sim 100 \mathrm{~m}$ de profundidad para obtener mediciones continuas de presión, temperatura, conductividad, oxígeno disuelto y fluorescencia. Se colectó agua de mar con botellas Niskin de $5 \mathrm{~L}$ de capacidad a 7 niveles ópticos de la zona eufótica correspondientes al 100\%, 50\%, 30\%, 20\%, 10\%, $1 \%$ y $0.1 \%$ de radiación fotosintéticamente activa (PAR) de la luz superficial $\left(\% \mathrm{E}_{\mathrm{o}}\right)$ y a la profundidad del máximo de fluorescencia (PMF). Para los análisis de clorofila a (Chla) (3 réplicas) y de pigmentos accesorios, se colectó y filtró $1 \mathrm{~L}$ de agua de mar por cada variable usando un filtro tipo GF/F de $25 \mathrm{~mm}$ de diámetro, que fue almacenado inmediatamente en nitrógeno líquido.

\section{Análisis rutinarios del agua de mar}

En el laboratorio, se determinó la concentración de Chla con un fluorómetro Turner Designs Trilogy mediante el método de fluorometría sin acidificar de Welschmeyer (1994). Se realizaron análisis de cromatografía líquida de alto desempeño (HPLC, por sus siglas en inglés) para determinar la concentración de pigmentos accesorios siguiendo las técnicas descritas por Almazán-Becerril y García-Mendoza (2008). La asignación taxonómica estuvo basada en la composición pigmentaria asociada a grupos fitoplanctónicos 


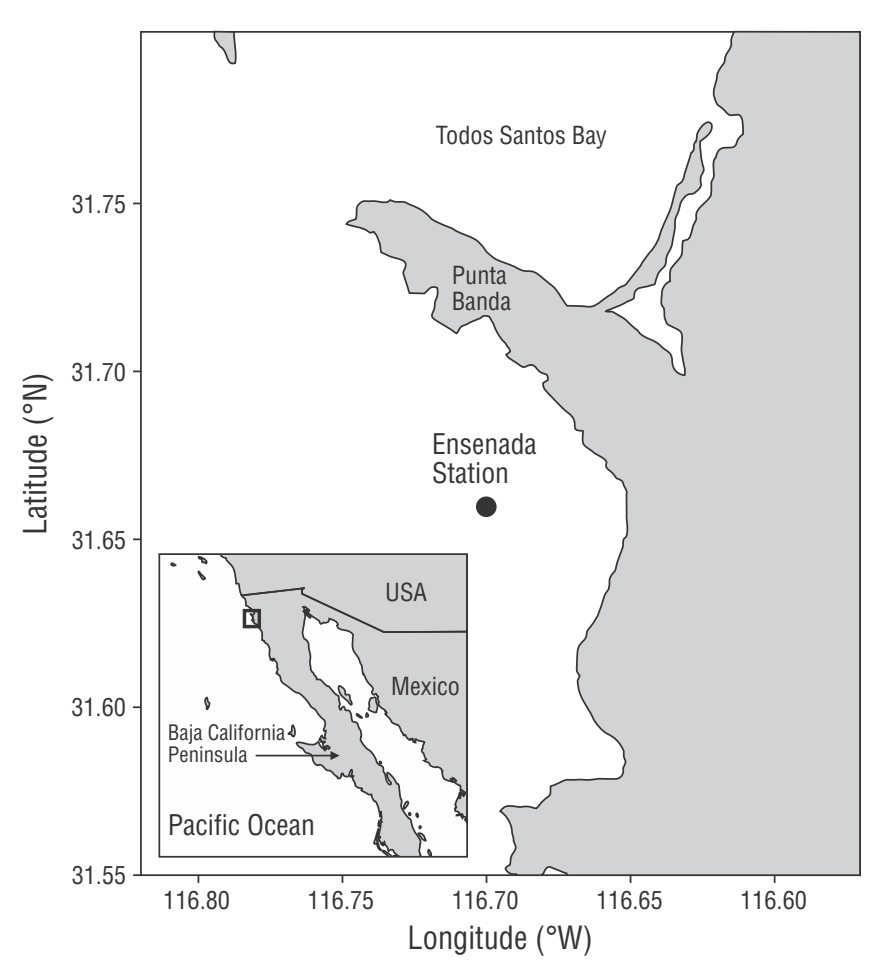

Figure 1. Location of the experimental site 'ENSENADA station' $\left(31.66^{\circ} \mathrm{N}, 116.7^{\circ} \mathrm{W}\right)$ in the northern coastal waters of western Baja California, Mexico.

Figura 1. Sitio experimental estación ENSENADA $\left(31.66^{\circ} \mathrm{N}\right.$, $116.7^{\circ} \mathrm{W}$ ) localizado en las aguas costeras de la región norte de Baja California, México.

Alloxanthin (Allox) is a specific marker for cryptophytes. To estimate the abundance of nano- and microplanktonic groups, $250 \mathrm{~mL}$ of seawater were collected with amber bottles at each depth level and fixed with $10 \%$ acid Lugol's solution (Throndsen 1978). At the laboratory, samples were settled in $10,25,55,75$, and $100 \mathrm{~mL}$ sedimentation chambers, depending on cell density, following the method of Utermöhl (1931). Quantification and taxonomic analyses were carried out using a Leica DMI3000B inverted microscope equipped with $10 \times, 20 \times, 40 \times$ and $63 \times$ objectives. Each sample was quantified until reaching a minimum count of 400 cells. In case of low cell density, the whole chamber was quantified. Diatoms, dinoflagellates, nanoflagellates (autotrophic), ciliates, tintinnids, and other minor autotrophic groups (including silicoflagellates and euglenoids) were identified and grouped using taxonomic keys (Tomas 1997, Omura et al. 2013). The microzooplankton group, as a potential mixotrophic consumer of phytoplankton, was represented by ciliates, tintinnids, and half of the dinoflagellate group according to the Linacre et al. (2012) approximation.

\section{Preparation of experimental incubations}

In order to simultaneously estimate phytoplankton growth and microzooplankton grazing rates, onboard experiments encontrados previamente en el sitio de estudio (Linacre et al. 2012). Divinil clorofila $a(D V-C h l a)$ es encontrada exclusivamente en poblaciones de Prochlorococcus. Zeaxantina (Zea) es mayormente asignada a poblaciones de cianobacterias. Fucoxantina (Fuco) se asume principalmente asociada a diatomeas, mientras que peridinina (Perid) sólo se encuentra en algunos grupos de dinoflagelados. Concentraciones de 19'-hexanoiloxifucoxantina (Hex-Fuco) y 19'-butanoiloxifucoxantina (But-Fuco) se encuentran mayormente en algunos grupos de nanoflagelados, tales como prymnesiofitas y pelagofitas, respectivamente. Las algas verdes nanoflageladas contienen en general clorofila $b(C h l b)$, incluyendo algunos tipos de prasinofitas, cuyo pigmento característico es la prasinoxantina (Pras). Aloxantina (Alox) se considera como pigmento específico de criptofitas. Para estimar la abundancia de los grupos nano- y microplanctónicos, se colectaron $250 \mathrm{~mL}$ de agua de mar en botellas oscuras a cada nivel de profundidad y se fijaron con una solución de Lugol ácido al 10\% (Throndsen 1978). En el laboratorio, las muestras se dejaron sedimentar en cámaras de sedimentación de 10, 25, 55,75 y $100 \mathrm{~mL}$, según la densidad celular, siguiendo el método de Utermöhl (1931). La cuantificación y el análisis taxonómico se realizaron mediante un microscopio invertido Leica DMI3000B equipado con objetivos de $10 \times, 20 \times, 40 \times$ y $63 \times$. Cada muestra fue cuantificada hasta alcanzar un mínimo de 400 células. En caso de encontrar densidad celular baja, se cuantificó la cámara completa. Con las claves taxonómicas (Tomas 1997, Omura et al. 2013), se identificaron y agruparon las células de dinoflagelados, diatomeas, nanoflagelados (autotróficos), ciliados, tintínidos y otros grupos autotróficos minoritarios (e.g., silicoflagelados y euglenas). Siguiendo la aproximación descrita por Linacre et al. (2012), el grupo del microzooplancton, como potencial consumidor autotrófico de la comunidad fitoplanctónica, estuvo representado por ciliados, tintínidos y la mitad del grupo de los dinoflagelados.

\section{Preparación de las incubaciones experimentales}

Durante el atardecer, se colectó agua de mar desde la PMF en OCT-15 $(\sim 14 \mathrm{~m})$ y ABR-16 $(\sim 5 \mathrm{~m})$ para realizar un experimento abordo. Esto permitió la estimación simultánea de las tasas de crecimiento del fitoplancton y su mortalidad por el pastoreo del microzooplancton siguiendo la técnica de dilución descrita por Landry y Hassett (1982). Cada experimento consistió en la preparación de 6 tratamientos que contenían una fracción de agua de mar "entera" colectada directamente de las botellas Niskin y otra de agua de mar "filtrada" a través de un filtro de $0.1 \mu \mathrm{m}(10 \%, 30 \%, 50 \%, 75 \%$, $100 \%$ de agua de mar "entera"), además de un control experimental con sólo agua de mar "filtrada" $(0 \%)$. A estos tratamientos se les adicionaron una mezcla de nutrientes (concentraciones finales de $4.9 \mu \mathrm{M}$ de nitrato y $0.3 \mu \mathrm{M}$ de fosfato) para asegurar un crecimiento óptimo del fitoplancton durante el periodo de la incubación. Con la finalidad de 
were conducted using seawater collected at the DFM depth in OCT-15 ( 14 m) and APR-16 ( $\sim 5 \mathrm{~m})$ during sunset, following the dilution technique described by Landry and Hassett (1982). Each experiment consisted of 6 treatments prepared with a fraction of "whole" seawater collected directly from the Niskin bottles and a fraction of "filtered" seawater passed through a $0.1 \mu \mathrm{m}$ filter $(10 \%, 30 \%, 50 \%, 75 \%, 100 \%$ "whole" seawater). An additional control experiment was conducted using only "filtered" seawater $(0 \%)$. These treatments were enriched with a mixture of nutrients $(4.9 \mu \mathrm{M}$ nitrate and $0.3 \mu \mathrm{M}$ phosphate, final concentrations) to ensure optimal phytoplankton growth during the incubation period. In order to estimate "natural" phytoplankton growth rate, an additional treatment was prepared with only "whole" seawater $(100 \%)$ and no additional nutrients. Each treatment and the replicates were incubated for a $24-\mathrm{h}$ time period $(t)$ in a blue acrylic container that simulated the optical conditions found in the euphotic zone $\left(\sim 36 \% \mathrm{E}_{\mathrm{o}}\right)$. The incubator was placed on the deck of the ship, exposed to sunlight, and connected to a continuous seawater flow to maintain the temperature of the mixed layer during the incubation period.

\section{Estimation of daily growth and grazing rates}

At the beginning and end $(t=24 \mathrm{~h})$ of the experimental incubations, seawater was collected to determine the Chla and taxon-specific pigment concentrations (initial, $C_{\mathrm{o}}$; final, $C_{t}$ ) assigned to phytoplankton groups. The temporal change in pigment concentration in each treatment (i), $k_{i}=$ $\ln \left(C_{t} / C_{\mathrm{o}}\right) / t$, was used to estimate the instantaneous daily growth rates $\left(\mathrm{d}^{-1}\right)$ of the phytoplankton community (based on Chla) and specific phytoplankton groups (based on taxonspecific pigments). A linear regression analysis between $k_{i}$ and each dilution factor $(0.10,0.30,0.50,0.75$, and 1.00$)$ was performed to simultaneously determine the daily growth rate of phytoplankton enriched with nutrients $\left(\mu_{\mathrm{n}}\right.$, intercept of the regression line) and the daily grazing rate by microzooplankton ( $m$, slope of the regression line). The "natural" growth rate $\left(\mu_{\mathrm{o}}\right)$ was calculated as the sum of the net growth rate in the undiluted treatment without nutrient addition $\left(k_{\mathrm{o}}\right)$ and $m$. The limitation in the growth rate of the phytoplankton community and specific autotrophic groups by insufficient environmental nutrients was estimated as the ratio $\mu_{\mathrm{o}}: \mu_{\mathrm{n}}$. Values of $\mu_{\mathrm{o}}: \mu_{\mathrm{n}}<1$ indicate limited growth rates under nutrient deficiency in the environment. Moreover, the $m: \mu_{\mathrm{o}}$ ratio was calculated as a measure of the daily microzooplankton grazing impact on primary production of the phytoplankton community and taxon-specific phytoplankton groups. Initial concentrations of Chla and taxon-specific pigments and the estimated growth and grazing rates were used to assess primary production (PP), protist consumption $(G)$, and the percentage of phytoplankton biomass consumed per day: $\mathrm{PP}=\mu_{o}\left(C_{o}\left[\mathrm{e}^{\left(\mu_{o-m) t}\right.}-1\right] /\left(\mu_{o}-m\right) t\right) ; G=m\left(C_{o}\left[\mathrm{e}^{\mu_{o-m) t}}-\right.\right.$ estimar la tasa "natural" del crecimiento del fitoplancton, se preparó adicionalmente un tratamiento con sólo agua de mar "entera" (100\%) sin la adición de nutrientes. Cada tratamiento y sus réplicas fueron incubados durante un periodo de tiempo $(t)$ de $24 \mathrm{~h}$ en un contenedor de acrílico azul que simuló las condiciones ópticas encontradas dentro de la zona eufótica $\left(\sim 36 \% \mathrm{E}_{\mathrm{o}}\right)$. El incubador se colocó sobre la cubierta del barco, expuesto a la luz solar, y se conectó a un flujo de agua de mar continuo que mantuvo la temperatura de la capa de mezcla durante la incubación.

\section{Estimación de las tasas diarias de crecimiento y pastoreo}

Al inicio y al final $(t=24 \mathrm{~h})$ de las incubaciones experimentales se colectó agua de mar para determinar las concentraciones iniciales $\left(C_{\mathrm{o}}\right)$ y finales $\left(C_{t}\right)$ de Chla y de los pigmentos accesorios característicos de ciertos grupos fitoplanctónicos. El cambio temporal en la concentración pigmentaria en cada tratamiento $(i), k_{i}=\ln \left(C_{t} / C_{\mathrm{o}}\right) / t$, permitió estimar las tasas instantáneas de crecimiento diario $\left(\mathrm{d}^{-1}\right)$ de la comunidad de fitoplancton (basadas en Chla) y de grupos fitoplanctónicos específicos (basadas en pigmentos característicos de cada grupo). Posteriormente, se realizó un análisis de regresión lineal entre $k_{i}$ y cada factor de dilución $(0.10$, $0.30,0.50,0.75$ y 1.00$)$ para determinar, simultáneamente, las tasas diarias de crecimiento de fitoplancton enriquecido con nutrientes $\left(\mu_{\mathrm{n}}\right)$ como el intercepto y la tasa de mortalidad $(\mathrm{m})$ por el pastoreo del microzooplancton como la pendiente de la regresión. La tasa de crecimiento "natural" $\left(\mu_{\mathrm{o}}\right)$ se calculó como la suma de la tasa neta de cambio del tratamiento realizado sin la adición de nutrientes $\left(k_{o}\right)$ y la tasa de pastoreo $(m)$. La limitación del crecimiento de la comunidad del fitoplancton y sus grupos específicos por la falta de nutrientes se estimó como la razón $\mu_{\mathrm{o}}: \mu_{\mathrm{n}}$. Valores de $\mu_{\mathrm{o}}: \mu_{\mathrm{n}}<1$ indican tasas de crecimiento limitadas bajo concentraciones insuficientes de nutrientes ambientales. Además, se calculó la razón $m: \mu_{\mathrm{o}}$ como una medida del impacto diario ejercido por el microzooplancton sobre la producción primaria diaria de la comunidad de fitoplancton y de grupos específicos de fitoplancton. Adicionalmente, con base en la concentración inicial de Chla y pigmentos característicos de grupos fitoplanctónicos, así como en sus tasas de crecimiento, se calcularon las variables derivadas de producción primaria (PP), consumo protista $(G)$ y el porcentaje de biomasa fitoplanctónica consumida por día como PP $=\mu_{\mathrm{o}}\left(C_{\mathrm{o}}\left[\mathrm{e}^{\left(\mu_{0-m) t}\right.}-1\right] /\left(\mu_{\mathrm{o}}-\right.\right.$ $m) t) ; G=m\left(C_{\mathrm{o}}\left[\mathrm{e}^{\mu_{0-m) t}}-1\right] /\left(\mu_{\mathrm{o}}-m\right) t\right) ; \mathrm{y} G \cdot 100 / C_{\mathrm{o}}$, respectivamente (Calbet y Landry 2004).

\section{RESUltados}

\section{Condiciones hidrográficas al inicio del experimento}

Durante la colecta de agua de mar de la PMF para las incubaciones experimentales llevadas a cabo en la estación 
1]/ $\left(\mu_{0}-m\right) t$ ); and $G \cdot 100 / C_{0}$, respectively (Calbet and Landry 2004).

\section{RESUlts}

\section{Initial hydrographic conditions}

During seawater collection at the DFM depth for the experimental incubations carried out at the ENSENADA station in OCT-15 and APR-16, marked seasonal differences in the hydrographic conditions of the surface water column $(<100 \mathrm{~m})$ were observed (Fig. 2). During OCT-15, the water column showed warmer waters $\left(\sim 15-21^{\circ} \mathrm{C}\right)$, higher salinity in the upper $10 \mathrm{~m}(\sim 33.5)$, and lower density $\left(\sigma_{\mathrm{t}} \sim\right.$ $\left.23.4-24.8 \mathrm{~kg} \cdot \mathrm{m}^{-3}\right)$. Although a shallow mixed layer $(\sim 10 \mathrm{~m})$ was observed during this cruise, similar to that observed in APR-16, the vertical temperature and density gradients were more pronounced, with a deeper thermocline depth $(\sim 45 \mathrm{~m})$. In APR-16, colder $\left(10.5-14.0^{\circ} \mathrm{C}\right)$ and less saline waters at the surface were observed, while at depths below $10 \mathrm{~m}$, significantly more saline $(\sim 33.5-33.6)$ and denser $\left(\sigma_{t} \sim\right.$ $25.0-25.5 \mathrm{~kg} \cdot \mathrm{m}^{-3}$ ) waters were recorded, likely due to spring upwelling events (Fig. 2a-c).

\section{Biological conditions within the euphotic zone}

The contrasting hydrographic conditions between OCT15 and APR-16 and the difference in the depth of the euphotic layer (57 m for OCT-15 and $24 \mathrm{~m}$ for APR-16 at $0.1 \% \mathrm{E}_{\mathrm{o}}$ ) were also evident in the variation of phytoplankton biomass (Chla) and abundance (cells $\cdot \mathrm{L}^{-1}$ ) in the euphotic zone (Fig. 3). Chla concentrations were higher in OCT-15 $\left(1.2-2.7 \mu \mathrm{g} \cdot \mathrm{L}^{-1}\right)$ than in APR-15 $\left(1.0-1.9 \mu \mathrm{g} \cdot \mathrm{L}^{-1}\right)$ but only up to $30 \% \mathrm{E}_{\mathrm{o}}$, where the maximum value $\left(2.7 \mu \mathrm{g} \cdot \mathrm{L}^{-1}\right)$ was recorded. Below that optical depth level, Chla concentrations in OCT-15 decreased significantly. In APR-16, the Chla maximum value $\left(2.3 \mu \mathrm{g} \cdot \mathrm{L}^{-1}\right)$ was recorded at $20 \% \mathrm{E}_{\mathrm{o}}$ (Fig. 3a). In general, phytoplankton abundance in OCT-15 was about half the abundance observed in APR-16 at all optical depth levels (Fig. 3b). Differences in the relative abundance of phytoplankton groups and their potential microzooplankton consumers were also observed between cruises (Fig. 4). During OCT-15, nanoflagellates and other minor groups comprised on average $\sim 40 \%$ of total autotrophs in the euphotic zone, but $>60 \%$ near the surface. Below $30 \% \mathrm{E}_{0}$, dinoflagellates and diatoms had higher relative importance (>70\%, Fig. $4 a)$. In contrast, in APR-16, $80 \%$ of total abundance at all optical depth levels was composed of diatoms, the dominant phytoplankton group during this season (Fig. $4 \mathrm{~b}$ ). In accordance to this relative distribution of autotrophs, potential microzooplankton consumers also displayed seasonal abundance variations. The warmer environmental conditions in OCT-15 favored a larger abundance of mixotrophic and heterotrophic dinoflagellates, which on average reached $\sim 70 \%$ of total
ENSENADA en OCT-15 y ABR-16, se observaron notables diferencias estacionales en las condiciones hidrográficas de la columna de agua superficial $(<100 \mathrm{~m})$ (Fig. 2). Durante OCT-15, la columna de agua fue más cálida $\left(\sim 15-21^{\circ} \mathrm{C}\right)$, más salina en los primeros $10 \mathrm{~m}(\sim 33.5)$ y menos densa $\left(\sigma_{\mathrm{t}} \sim\right.$ $\left.23.4-24.8 \mathrm{~kg} \cdot \mathrm{m}^{-3}\right)$. En esta fecha, aunque se observó una capa de mezcla somera y similar a la observada en ABR-16 $(\sim 10 \mathrm{~m})$, el gradiente vertical de temperatura y densidad fue más pronunciado y la base de la termoclina fue más profunda $(\sim 45 \mathrm{~m})$. En ABR-16, aguas más frías $\left(10.5-14.0^{\circ} \mathrm{C}\right)$, menos salinas en la superficie, aunque notablemente más salinas por debajo de $10 \mathrm{~m}(\sim 33.5-33.6)$, y más densas $\left(\sigma_{\mathrm{t}} \sim\right.$ $\left.25.0-25.5 \mathrm{~kg} \cdot \mathrm{m}^{-3}\right)$ fueron registradas, posiblemente debido a eventos de surgencia en primavera (Fig. 2a-c).

\section{Condiciones biológicas dentro de la zona eufótica}

El contraste registrado en las condiciones hidrográficas entre OCT-15 y APR-16, y la diferencia en la profundidad de la zona eufótica (57 m en OCT-15 y $24 \mathrm{~m}$ en ABR-16 hasta el $0.1 \% \mathrm{E}_{\mathrm{o}}$ ) se vieron también reflejados en las diferencias observadas en la biomasa (Chla) y abundancia fitoplanctónica (células $\cdot \mathrm{L}^{-1}$ ) dentro de la zona eufótica (Fig. 3). Las concentraciones de Chla fueron más altas en OCT-15 $\left(1.2-2.7 \mu \mathrm{g} \cdot \mathrm{L}^{-1}\right)$ que en ABR-15 $\left(1.0-1.9 \mu \mathrm{g} \cdot \mathrm{L}^{-1}\right)$, pero sólo hasta el $30 \%$ de $\mathrm{E}_{0}$, donde se registró la concentración máxima $\left(2.7 \mu \mathrm{g} \cdot \mathrm{L}^{-1}\right)$. A partir de ese nivel óptico, los valores de Chla en OCT-15 disminuyeron notablemente. En ABR-16, se registró la máxima concentración de Chla $\left(2.3 \mu \mathrm{g} \cdot \mathrm{L}^{-1}\right)$ en el $20 \%$ de $\mathrm{E}_{\mathrm{o}}$ (Fig. 3a). En general, la abundancia fitoplanctónica registrada en OCT-15 fue aproximadamente la mitad de la observada en ABR-16 en todos los niveles ópticos (Fig. 3b). Además, se observaron diferencias en la abundancia relativa de los grupos fitoplanctónicos y sus potenciales predadores en cada crucero (Fig. 4). Durante OCT-15, los nanoflagelados y otros grupos minoritarios contribuyeron, en promedio, $\sim 40 \%$ de los autótrofos dentro de la zona eufótica, pero $>60 \%$ en niveles superficiales. Por debajo del $30 \%$ de $\mathrm{E}_{\mathrm{o}}$, los dinoflagelados y las diatomeas tuvieron mayor importancia relativa ( $>70 \%$, Fig. $4 a)$. En cambio, en ABR-16 80\% de la abundancia total en todos los niveles ópticos estuvo compuesta por diatomeas, el grupo fitoplanctónico dominante en esta época (Fig. 4b). De acuerdo con esta distribución relativa de autótrofos, sus potenciales predadores también mostraron variabilidad estacional en sus abundancias. En OCT-15 las condiciones ambientales más cálidas favorecieron una mayor abundancia de dinoflagelados mixotróficos y heterotróficos, que en promedio alcanzaron $\sim 70 \%$ del total de predadores potenciales dentro de la zona eufótica; por otro lado, durante la época de surgencia primaveral en ABR-16, los ciliados mixotróficos fueron los mayores componentes de la comunidad microzooplanctónica $(\sim 60 \%$ en promedio) (Fig. 4c-d). 


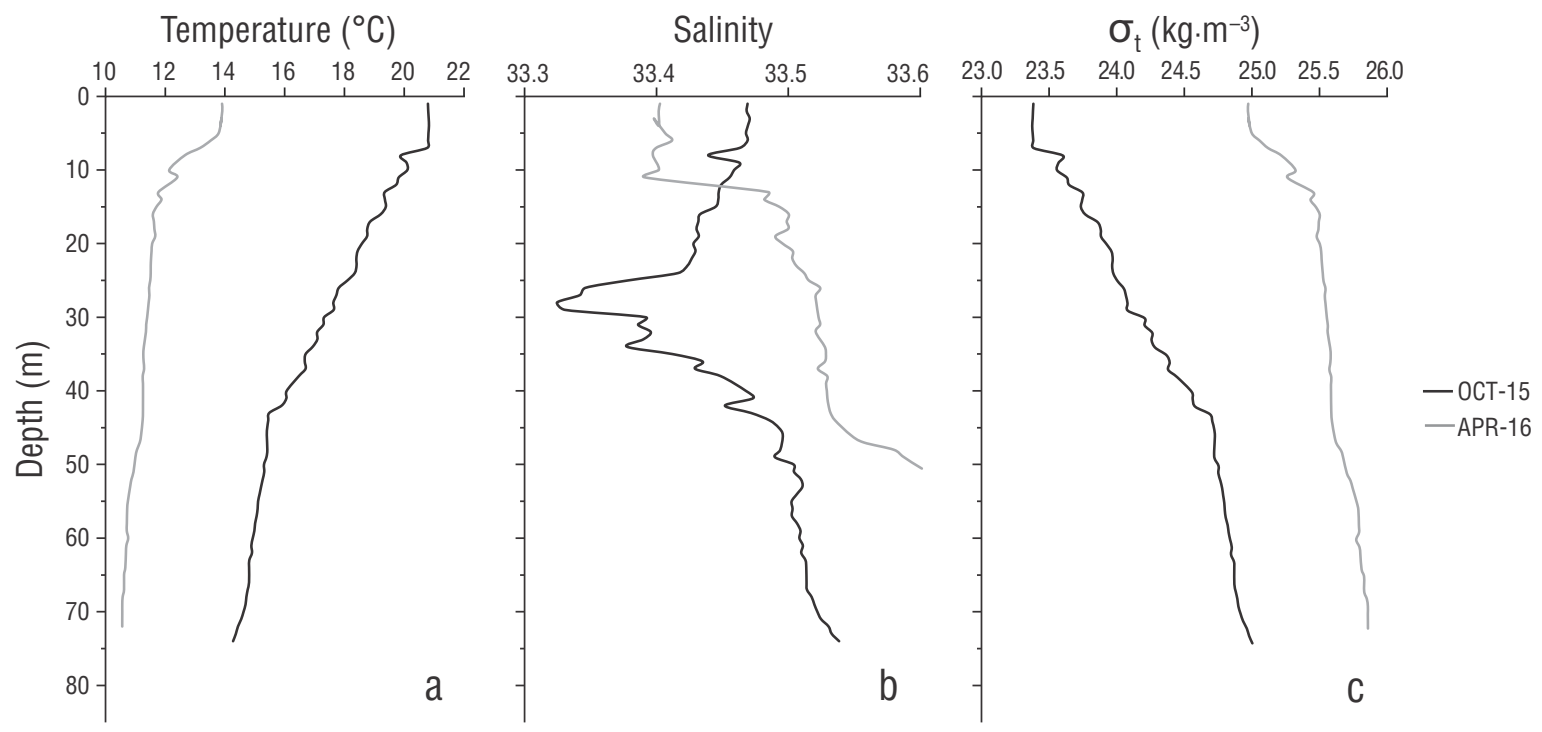

Figure 2. Hydrographic properties in the water column at the ENSENADA station during seawater collection for experimental incubations. Temperature (a), salinity (b), and density $\left(\sigma_{t}\right)$ (c) profiles for October 2015 (OCT-15) and April 2016 (APR-16) are shown.

Figura 2. Propiedades hidrográficas de la columna de agua en la estación ENSENADA durante la colecta de agua de mar para las incubaciones experimentales. Se muestran los perfiles de temperatura (a), salinidad (b) y densidad $\left(\sigma_{t}\right)$ (c) para octubre de $2015($ OCT-15) y abril de 2016 (APR-16).

potential consumers in the euphotic zone. During the spring upwelling event in APR-16, mixotrophic ciliates were the major components of microzooplankton ( $\sim 60 \%$ on average) (Fig. 4c-d).

\section{Growth and grazing estimates and microzooplankton grazing impact}

Differences were observed in the instantaneous rates of natural growth $\left(\mu_{\mathrm{o}}\right)$, enriched growth $\left(\mu_{\mathrm{n}}\right)$, and grazing $(m)$, as well as in primary production (PP) and daily microzooplankton consumption $(G)$ on the phytoplankton community between OCT-15 and APR-16 (Table 1). Strong limitation by nutrients $\left(\mu_{\mathrm{o}}: \mu_{\mathrm{n}}<1\right)$ was observed in the phytoplankton growth rate in OCT-15, with $\mu_{\mathrm{o}}$ almost 10 times lower than $m$ (Table 1). The same pattern was recorded for some taxonspecific growth rates (Table 2). Particularly in OCT-15, negative $\mu_{\mathrm{o}}$ estimates were observed for Fuco and Pras, and they were associated with the null growing of diatoms and prasinophytes, respectively. Other nano- and picoplanktonic groups, including cryptophytes and cyanobacteria assigned to Allox and Zea, respectively, showed very high $\mu_{\mathrm{o}}$ values and were apparently not limited by nutrient deficiency $\left(\mu_{\mathrm{o}}: \mu_{\mathrm{n}} \approx 1\right)$ (Table 2). In contrast, growth rates for the phytoplankton community and specific groups were not limited by nutrients in APR-16, with $\mu_{\mathrm{o}}$ up to 3 times higher than $m$ (Tables 1, 2). Moreover, accessory pigment concentrations that were below the detection limit in previous seasons and are representative of some autotrophic nano- and microplankton groups, such as

\section{Estimaciones de las tasas de crecimiento y pastoreo e impacto diario del microzooplancton}

Se observaron diferencias tanto en las tasas instantáneas de crecimiento natural $\left(\mu_{\mathrm{o}}\right)$, crecimiento enriquecido $\left(\mu_{\mathrm{n}}\right)$ y pastoreo $(m)$ como en las tasas de productividad primaria $(P P)$ y consumo $(G)$ diario ejercido por el microzooplancton sobre la comunidad fitoplanctónica entre OCT-15 y ABR-16 (Tabla 1). Se encontró una fuerte limitación por nutrientes $\left(\mu_{\mathrm{o}}: \mu_{\mathrm{n}}<1\right)$ en la tasa de crecimiento del fitoplancton en OCT15 , con un valor de $\mu_{\mathrm{o}}$ casi 10 veces más bajo que el de $m$ (Tabla 1). El mismo patrón fue registrado para algunas de las tasas específicas que caracterizaron a ciertos grupos fitoplanctónicos (Tabla 2). Particularmente en OCT-15, se observaron estimaciones negativas de $\mu_{\mathrm{o}}$ para Fuco y Pras asociadas al crecimiento nulo de diatomeas y prasinofitas, respectivamente. Otros grupos nano- y picoplanctónicos, como criptofitas y cianobacterias que se relacionan a Alox y Zea, respectivamente, presentaron valores de $\mu_{\mathrm{o}}$ muy altos $\mathrm{y}$ aparentemente no estuvieron limitados por escasez de nutrientes $\left(\mu_{\mathrm{o}}: \mu_{\mathrm{n}} \approx 1\right)$ (Tabla 2 ). En ABR-16 la comunidad de fitoplancton $\mathrm{y}$, en general, los grupos específicos presentaron tasas de crecimiento no limitadas por nutrientes, con valores de $\mu_{\mathrm{o}}$ hasta 3 veces más altos que los de $m$ (Tablas 1,2 ). Además, durante esa época de primavera se detectaron concentraciones de algunos pigmentos accesorios que en épocas previas estuvieron por debajo del límite de detección y que son representativos de algunos autótrofos nano- y microplanctónicos, como algunos tipos de dinoflagelados (Perid), 
some types of dinoflagellates (Perid), prymnesiophytes (Hex-Fuco), and pelagophytes (But-Fuco), were detected during that spring season, allowing taxon-specific growth and grazing rates to be estimated (Table 2). High $\mu_{\mathrm{o}}$ values for diatoms (Fuco), dinoflagellates (Perid) and chlorophytes (Chlb), including prasinophytes (Pras), were observed in APR-16, whereas low growth rates were observed in cryptophytes (Allox) and cyanobacteria (Zea) (Table 2). In OCT-15, $G$ >> PP values were estimated for the phytoplankton community and specific phytoplankton groups, while in APR-16 $G$ was always lower than or equal to (e.g., cyanobacteria) community and taxon-specific PP (Tables 1,2 ). In addition, the differences in PP and $G$ observed between the 2 seasons were reflected upon microzooplankton grazing pressure ( $m: \mu=\mathrm{PP}: \mathrm{G})$ on the initial biomass $\left(C_{\mathrm{o}}\right)$ and daily PP of the phytoplankton community and on taxon-specific PP (Fig. 5). During OCT-15, grazing impact on $C_{\mathrm{o}}$ was, on average, $72 \%$ (Fig. 5a), and grazing impact on community PP (Fig. 5b) and on PP of some small autotrophs was $>100 \%$ (Fig. $5 \mathrm{c}$ ). In contrast, an average microzooplancton impact of $62 \%$ on $C_{\mathrm{o}}$ (Fig. 5a), 34\% on community PP (Fig. 5b) and, overall, 51\% on specific groups (Fig. 5c) was recorded in APR-16.

\section{DISCUSSION}

This study was conducted in a coastal upwelling system (ENSENADA station) that is representative of the physicochemical conditions off northern Baja California $(<50 \mathrm{~km})$. The system is characterized as a CCS transition zone because it is influenced by arctic waters from the north and tropical/ subtropical waters from the south (Linacre et al. 2010b). Historical analysis of temperature and salinity records indicate that the ENSENADA station reflects seasonal changes in the water column hydrography of this CCS region, which are associated with coastal upwelling events (frequent and intense in spring-summer) and with the mesoscale circulation activity in summer, autumn, and winter. The ENSENADA station is also a site that is susceptible to interannual events, such as La Niña 2007-2008 (Linacre et al. 2010b).

During the present study, 2 anomalous warming events were observed in CCS waters: "The warm Blob" 2013-2015 (Cavole et al. 2016) and El Niño 2015-2016 (Jacox et al. 2016). Both events apparently influenced the thermohaline conditions in the upper layer of the water column $(<100 \mathrm{~m})$, mainly in OCT- 15 , when warmer $\left(\sim 3-4{ }^{\circ} \mathrm{C}\right)$ and more saline $(\sim 0.1)$ waters than expected in a climatological autumn (data not shown) were observed at this coastal site. These observations are consistent with the temperature and salinity anomalies recorded in northern Baja California by the IMECOCAL program (Durazo et al. 2017). During APR-16, the temperature and salinity profiles show an apparent return to spring conditions in this coastal upwelling system and, although to a lesser extent, this recovery was also evident towards more oceanic northern Baja California areas.

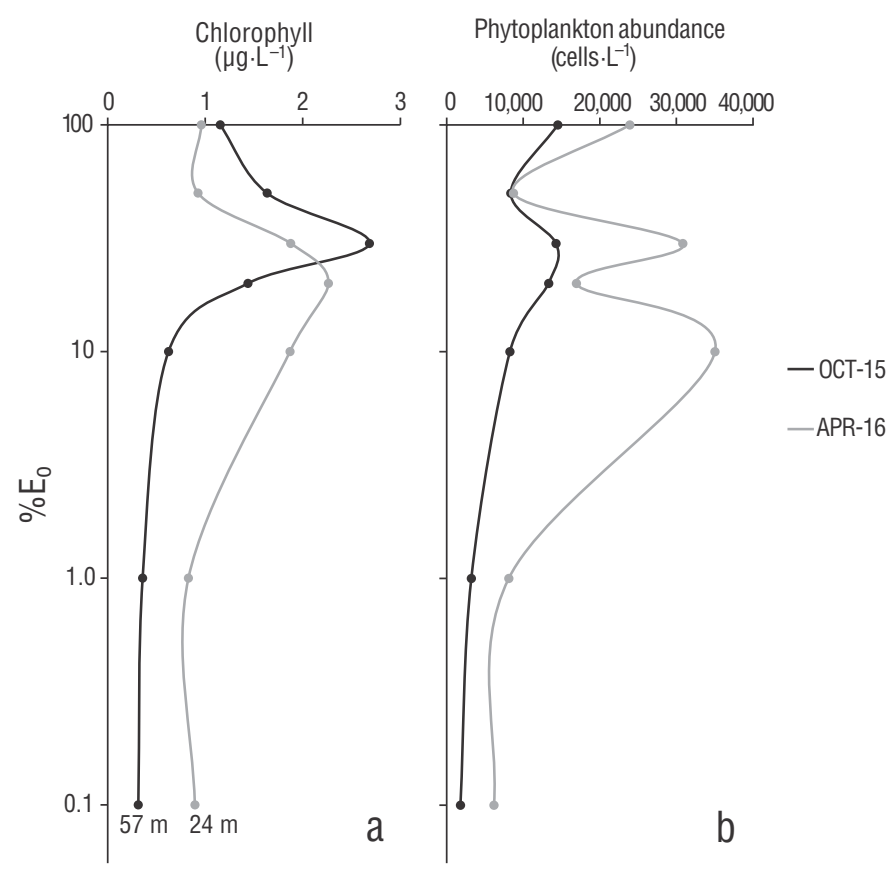

Figure 3. Chlorophyll a concentrations (a) and total phytoplankton abundance (b) in the euphotic zone at the ENSENADA station in October 2015 (OCT-15) and April 2016 (APR-16). Panel (a) shows the depth of the euphotic zone for each period. $\% \mathrm{E}_{\mathrm{o}}$ indicates the percentage of surface photosynthetically active radiation.

Figura 3. Concentración de clorofila $a$ (a) y abundancia total de fitoplancton (b) observadas dentro de la zona eufótica de la estación ENSENADA durante octubre de 2015 (OCT-15) y abril de 2016 (APR-16). En el panel (a) se indica la profundidad de la zona eufótica para cada periodo. \%Eo indica el porcentaje de la radiación fotosintéticamente activa de la luz superficial.

prymnesiofitas (Hex-Fuco) y pelagofitas (But-Fuco), lo que permitió estimar las tasas específicas de crecimiento y pastoreo (Tabla 2). Se observaron altos valores de $\mu_{\mathrm{o}}$ de diatomeas (Fuco), dinoflagelados (Perid) y clorofitas (Chlb), incluyendo prasinofitas (Pras), durante ABR-16, en contraste con las bajas tasas de crecimiento observadas en criptofitas (Alox) y cianobacterias (Zea) (Tabla 2). Respecto a las tasas diarias de producción y pérdida de fitoplancton, en OCT-15 se estimaron valores de $G$ >> PP tanto para la comunidad como para los grupos específicos de fitoplancton, mientras que en ABR-16, $G$ siempre fue menor o igual (caso de cianobacterias) que la PP comunitaria y específica (Tablas 1,2). Las diferencias observadas en PP y $G$ entre ambas temporadas, se reflejaron en la presión de pastoreo ( $m: \mu=\mathrm{PP}: \mathrm{G})$ que ejerció el microzooplancton sobre la biomasa inicial $\left(C_{\mathrm{o}}\right)$ y la PP diaria de la comunidad fitoplanctónica y sobre la PP de grupos específicos (Fig. 5). Durante OCT-15 se registraron un promedio de pastoreo del $72 \%$ sobre $C_{\mathrm{o}}$ (Fig. 5a) y valores del impacto sobre la PP comunitaria (Fig. 5b) y PP de algunos autótrofos pequeños $>100 \%$ (Fig. 5c). Esto contrastó con las 


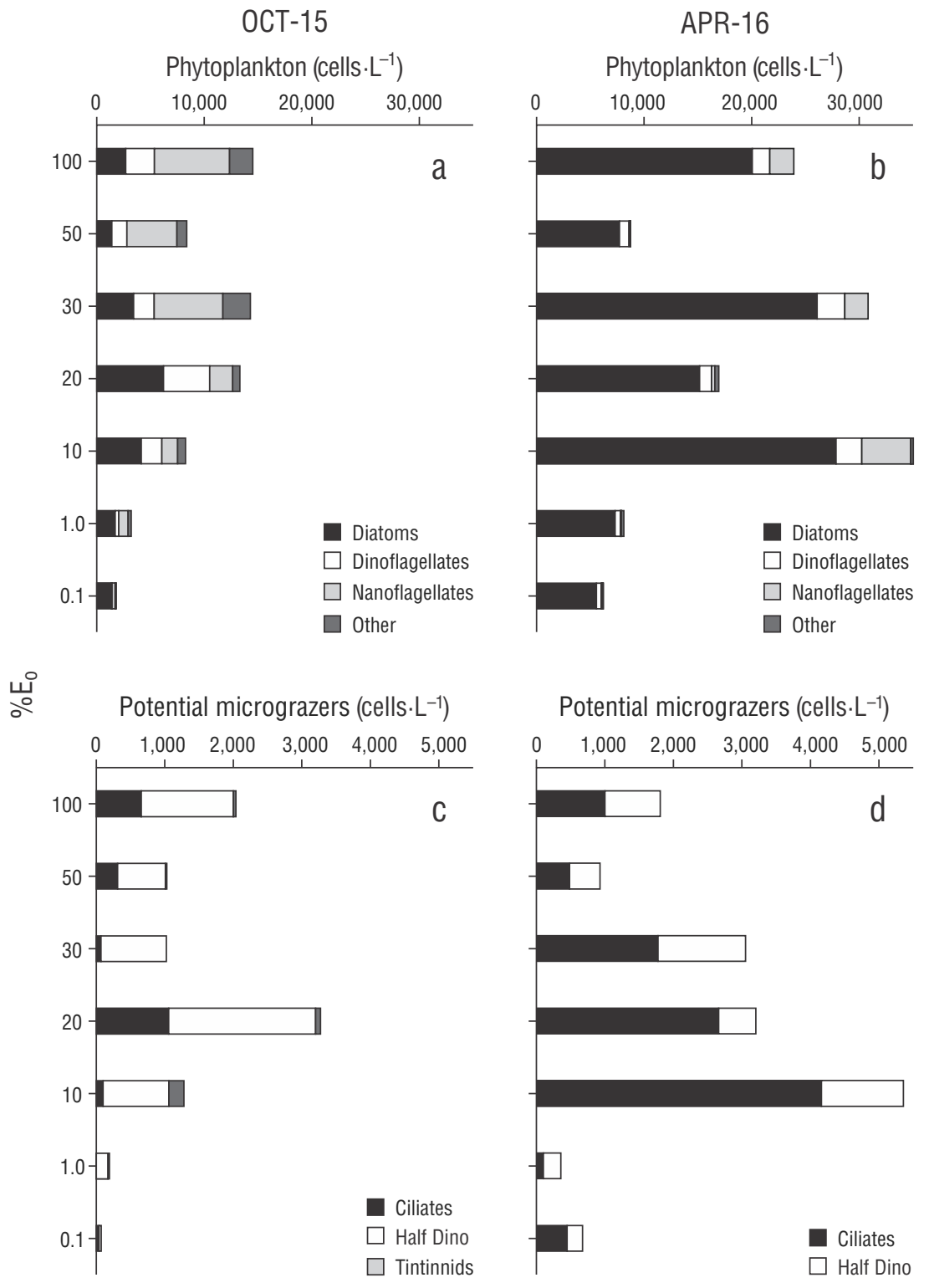

Figure 4. Relative abundance of phytoplankton groups (a, b) and their potential microzooplankton consumers (c, d) in the euphotic zone at the ENSENADA station in October 2015 (OCT-15) and April 2016 (APR-16). \% $\mathrm{E}_{\mathrm{o}}$ indicates the percentage of surface photosynthetically active radiation.

Figura 4. Abundancia relativa de los grupos fitoplanctónicos (a, b) y de sus potenciales predadores microzooplanctónicos (c, d) observada dentro de la zona eufótica de la estación ENSENADA durante octubre de 2015 (OCT-15) y abril de 2016 (APR-16). \% $\mathrm{E}_{\mathrm{o}}$ indica el porcentaje de la radiación fotosintéticamente activa de la luz superficial.

Under this environmental context of interannual variability - and partly seasonal variability - significant differences in hydrographic conditions were observed in this study. These differences likely influenced not only nutrient availability for phytoplankton in the euphotic zone (McClatchie et al. 2016, Zaba and Rudnick 2016) but also the contrasts observed in phytoplankton growth rates $(\mu)$ and, consequently, in daily community PP (based on Chla) and taxonspecific PP (based on specific pigments) between OCT-15 and APR-16. Since no information on nutrient concentrations was available for this study, reference nitrate levels reported estimaciones hechas para ABR-16 de un impacto promedio del $62 \%$ sobre $C_{\text {o }}$ (Fig. 5a), 34\% sobre la PP comunitaria (Fig. 5b) y, globalmente, 51\% sobre los grupos específicos (Fig. 5c).

\section{Discusión}

Este estudio fue realizado en un sistema de surgencia costera (estación ENSENADA) que es representativo de las condiciones fisicoquímicas de la región norte de Baja California $(<50 \mathrm{~km})$ y que es caracterizado como una zona de transición 
Table 1. Depth of maximum fluorescence (DFM, in meters) at which seawater was collected for the dilution experiments; chlorophyll $a$ initial concentration (mean \pm standard error) $\left(C_{0}, \mu \mathrm{g} \cdot \mathrm{L}^{-1}\right)$; instantaneous rates (mean \pm standard error) of natural growth $\left(\mu_{\mathrm{o}}, \mathrm{d}^{-1}\right)$, enriched growth $\left(\mu_{\mathrm{n}}, \mathrm{d}^{-1}\right)$, and grazing of the phytoplankton community (chlorophyll- $a$ based) consumed by microzooplankton $\left(m, \mathrm{~d}^{-1}\right)$; nutrient limitation index $\left(\mu_{\mathrm{o}}: \mu_{\mathrm{n}}\right)$; daily phytoplankton (chlorophyll-a based) primary production (PP, $\mu \mathrm{g}$ Chla $\left.\cdot \mathrm{L}^{-1} \cdot \mathrm{d}^{-1}\right)$ and microzooplankton consumption $(G$, $\mu \mathrm{g}$ Chla $\left.\cdot \mathrm{L}^{-1} \cdot \mathrm{d}^{-1}\right)$ rates; microzooplankton grazing impact on phytoplankton biomass (\%Chla standing stock [SS] grazed, $\left.\mathrm{d}^{-1}\right)$; and percentage of microzooplankton grazing impact on daily primary production (\%PP grazed). Values shown are those estimated at the ENSENADA station during this study (OCT-15 and APR-16) in comparison with values obtained in November 2008 (NOV-08), November 2007 (NOV-07), and April 2008 (APR-08).

Tabla 1. Profundidad del máximo de fluorescencia (DFM, en metros) donde se colectó el agua de mar para los experimentos de dilución; concentración inicial (promedio \pm error estándar) de clorofila $a\left(C_{\mathrm{o}}, \mu \mathrm{g}\right.$ Chla $\left.\cdot \mathrm{L}^{-1}\right)$; tasas instantáneas (promedio \pm error estándar) de crecimiento natural $\left(\mu_{\mathrm{o}}, \mathrm{d}^{-1}\right)$, de crecimiento enriquecido $\left(\mu_{\mathrm{n}}, \mathrm{d}^{-1}\right)$ y de mortalidad $\left(m, \mathrm{~d}^{-1}\right)$ de la comunidad de fitoplancton (basadas en clorofila $\left.a\right)$ por efecto del pastoreo del microzooplancton; índice de limitación por nutrientes $\left(\mu_{\mathrm{o}}: \mu_{\mathrm{n}}\right)$; tasas diarias (basadas en clorofila $a$ ) de producción primaria (PP, $\left.\mu \mathrm{g} \mathrm{Chla} \cdot \mathrm{L}^{-1} \cdot \mathrm{d}^{-1}\right)$ y consumo $\left(G, \mu \mathrm{g} \mathrm{Chla} \cdot \mathrm{L}^{-1} \cdot \mathrm{d}^{-1}\right)$ protista de fitoplancton; impacto de pastoreo sobre la biomasa fitoplanctónica (\%Chla standing stock $[\mathrm{SS}]$ grazed, $\left.\mathrm{d}^{-1}\right)$; y porcentaje de impacto de pastoreo sobre la PP diaria (\%PP grazed). Se muestran los valores estimados experimentalmente en la estación ENSENADA durante los periodos del presente estudio (octubre de 2015 [OCT-15] y abril de 2016 [APR-16]) comparados con los valores obtenidos en noviembre de 2008 (NOV-08), noviembre de 2007 (NOV-07) y abril de 2008 (APR-08).

\begin{tabular}{ccccccccccc}
\hline Cruise & $\begin{array}{c}\mathrm{DFM} \\
(\mathrm{m})\end{array}$ & $C_{\mathrm{o}}$ & $\mu_{\mathrm{o}}$ & $\mu_{\mathrm{n}}$ & $m$ & $\mu_{\mathrm{o}}: \mu_{\mathrm{n}}$ & PP & $\begin{array}{c}\text { \%Chla } \\
\mathrm{SS} \\
\text { grazed } \\
\text { grazed }\end{array}$ \\
\end{tabular}

\begin{tabular}{lrlllllllllll}
\hline Autumn & & & & & & & & & & \\
OCT-15 & 14 & $2.64 \pm 0.03$ & $0.12 \pm 0.01$ & $0.70 \pm 0.14$ & $1.14 \pm 0.05$ & 0.17 & 0.20 & 1.89 & 71.60 & 957.24 & This study \\
NOV-08 & 10 & $2.53 \pm 0.07$ & $0.30 \pm 0.02$ & $0.22 \pm 0.03$ & $0.48 \pm 0.06$ & 1.33 & 0.68 & 1.10 & 43.57 & 161.44 & Linacre, unpublished data \\
NOV-07 & 15 & $0.81 \pm 0.03$ & $0.47 \pm 0.03$ & $0.47 \pm 0.03$ & $0.13 \pm 0.05$ & 1.00 & 0.46 & 0.13 & 15.70 & 27.70 & Linacre, unpublished data \\
& & & & & & & & & & & & \\
Spring & & & & & & & & & & & \\
APR-16 & 5 & $2.08 \pm 0.03$ & $1.19 \pm 0.00$ & $1.04 \pm 0.05$ & $0.41 \pm 0.09$ & 1.14 & 3.73 & 1.29 & 61.84 & 34.47 & This study \\
APR-08 & 13 & $2.79 \pm 0.05$ & $0.66 \pm 0.01$ & $0.57 \pm 0.02$ & $0.49 \pm 0.03$ & 1.16 & 1.99 & 1.49 & 53.42 & 74.94 & Linacre, unpublished data \\
\hline
\end{tabular}

for the CalCOFI region in the CCS were considered. In this region, during 2015-2016, average nitrate values in the mixed layer were low, and the thermocline was unusually deeper, in comparison with the previous 15 years, because of marked stratification in the upper $100 \mathrm{~m}$ of the water column (McClatchie et al. 2016). The low availability of inorganic nutrients in the CCS led to low Chla concentrations in 2015, due to moderate upwelling events and El Niño 2015-2016, particularly in the southern California coastal area. For the northern IMECOCAL region, which is near the study area, negative anomalies of integrated Chla over the upper $100 \mathrm{~m}$ were reported in the system during autumn 2015. By April 2016, Chla concentrations apparently returned to levels close to the climatological average (McClatchie et al. 2016). According to these reports, the low temperatures $\left(<14{ }^{\circ} \mathrm{C}\right)$ recorded in the euphotic zone at the study area in APR-16 may indicate upwelling of cold nutrient-rich subsurface water, once the system returned to its normal conditions (Durazo et al. 2017). The dominance of diatoms in APR-16 might be an indication of this nutrient enrichment by upwelling, since vertical turbulence increases the proportion of larger cells in the illuminated layer (Rodríguez et al. 2001, Linacre et al. 2012). The higher surface temperatures del SCC porque está influenciado por aguas subárticas desde el norte y aguas tropicales/subtropicales desde el sur (Linacre et al. 2010b). Con base en un análisis histórico de registros de temperatura y salinidad, se ha determinado que la estación ENSENADA refleja los cambios estacionales que ocurren en la hidrografía de la columna de agua de esta región del SCC, los cuales están asociados a los frecuentes e intensos eventos de surgencia costera de primavera-verano y a la actividad de mesoescala de los patrones de circulación de verano, otoño e invierno. La estación ENSENADA es también un sitio susceptible a eventos interanuales, tales como La Niña 2007-2008 (Linacre et al. 2010b).

Durante la realización del presente estudio, 2 eventos de calentamiento anómalo fueron observados en las aguas del SCC: "The warm Blob" (Cavole et al. 2016) y El Niño 2015-2016 (Jacox et al. 2016). Estos eventos aparentemente causaron cambios en las condiciones termohalinas de la columna de agua superficial $(<100 \mathrm{~m})$ en la estación ENSENADA, principalmente en OCT-15, cuando se manifestaron aguas más cálidas $\left(\sim 3-4{ }^{\circ} \mathrm{C}\right)$ y más salinas $(\sim 0.1)$ de lo normalmente esperado en un otoño climatológico (datos no mostrados). Estas observaciones son consistentes con las anomalías respectivas que han sido registradas en la región 
Table 2. Initial concentration $\left(C_{\mathrm{o}}, \mu \mathrm{g} \cdot \mathrm{L}^{-1}\right)$ of accessory pigments associated with specific phytoplankton groups such as diatoms (fucoxanthin: Fuco), dinoflagellates (peridinin: Perid), prymnesiophytes (19'-hexanoyloxyfucoxanthin: Hex-Fuco), pelagophytes (19'butanoyloxyfucoxanthin: But-Fuco), prasinophytes (prasinoxanthin: Pras), green algae (chlorophyll b: Chlb), cryptophytes (alloxanthin: Allox), cyanobacteria (zeaxanthin: Zea), and Prochloroccus spp. (divinyl chlorophyll $a$ : DV-Chla). The instantaneous natural growth $\left(\mu_{\mathrm{o}}, \mathrm{d}^{-1}\right.$ ), enriched growth $\left(\mu_{\mathrm{n}}, \mathrm{d}^{-1}\right)$, and grazing $\left(m, \mathrm{~d}^{-1}\right)$ rates for specific phytoplankton groups consumed by microzooplankton were estimated based on taxon-specific pigments, nutrient limitation index $\left(\mu_{\mathrm{o}}: \mu_{\mathrm{n}}\right)$, and daily taxon-specific (specific pigment-based) primary production $\left(\mathrm{PP}, \mu \mathrm{g} \cdot \mathrm{L}^{-1} \cdot \mathrm{d}^{-1}\right)$ and microzooplankton consumption $\left(G, \mu \mathrm{g} \cdot \mathrm{L}^{-1} \cdot \mathrm{dd}^{-1}\right)$ rates. Experimental values were estimated at the ENSENADA station during this study (OCT-15 and APR-16).

Tabla 2. Concentración inicial $\left(C_{0}, \mu \mathrm{g} \cdot \mathrm{L}^{-1}\right)$ de pigmentos accesorios asociados a grupos específicos de fitoplancton como diatomeas (fucoxantina: Fuco), dinoflagelados (peridinina: Perid), prymnesiofitas (19'-hexanoiloxifucoxantina: Hex-Fuco), pelagofitas (19'butanoiloxifucoxantina: But-Fuco), prasinofitas (prasinoxantina: Pras), algas verdes en general (clorofila b: Chlb), criptofitas (aloxantina: Alox), cianobacterias (zeaxantina: Zea) y Prochloroccus spp. (divinil clorofila a: DVChla). Las estimaciones de las tasas instantáneas de crecimiento natural $\left(\mu_{\mathrm{o}}, \mathrm{d}^{-1}\right)$, crecimiento enriquecido $\left(\mu_{\mathrm{n}}, \mathrm{d}^{-1}\right)$ de grupos fitoplanctónicos y mortalidad por efecto del pastoreo del microzooplancton $\left(m, \mathrm{~d}^{-1}\right)$ están basadas en los pigmentos específicos, el índice de limitación por nutrientes $\left(\mu_{\mathrm{o}}: \mu_{\mathrm{n}}\right)$ y las tasas diarias (basadas en concentración pigmentaria) de producción primaria (PP, $\left.\mu \mathrm{g} \cdot \mathrm{L}^{-1} \cdot \mathrm{d}^{-1}\right)$ y consumo protista $\left(G, \mu \mathrm{g} \cdot \mathrm{L}^{-1} \cdot \mathrm{d}^{-1}\right)$. Los valores fueron estimados experimentalmente en la estación ENSENADA durante octubre de 2015 (OCT-15) y abril de 2016 (APR-16).

\begin{tabular}{lccccccccc}
\hline OCT-15 & Fuco & Perid & Hex-Fuco & But-Fuco & Pras & Chlb & Allox & Zea & DV-Chla \\
\hline$C_{\mathrm{o}}$ & 0.50 & nd & nd & nd & 0.16 & 0.25 & 0.19 & 0.18 & 0.08 \\
$\mu_{\mathrm{o}}$ & -0.10 & $\mathrm{nd}$ & $\mathrm{nd}$ & $\mathrm{nd}$ & -0.84 & 0.20 & 1.32 & 0.90 & 0.10 \\
$\mu_{\mathrm{n}}$ & 0.10 & $\mathrm{nd}$ & $\mathrm{nd}$ & $\mathrm{nd}$ & 0.50 & 0.62 & 1.94 & 0.97 & 0.08 \\
$m$ & 1.25 & $\mathrm{nd}$ & $\mathrm{nd}$ & $\mathrm{nd}$ & 1.07 & 0.87 & 2.68 & 0.71 & 0.74 \\
$\mu_{\mathrm{o}}: \mu_{\mathrm{n}}$ & $0.10^{*}$ & $\mathrm{nd}$ & $\mathrm{nd}$ & $\mathrm{nd}$ & $0.02^{*}$ & 0.32 & 0.68 & 0.93 & 1.31 \\
$\mathrm{PP}$ & $0.00^{*}$ & $\mathrm{nd}$ & $\mathrm{nd}$ & $\mathrm{nd}$ & $0.00^{*}$ & 0.04 & 0.14 & 0.18 & 0.01 \\
$G$ & 0.36 & $\mathrm{nd}$ & $\mathrm{nd}$ & $\mathrm{nd}$ & 0.11 & 0.16 & 0.28 & 0.14 & 0.04 \\
\hline APR-16 & Fuco & Perid & Hex-Fuco & But-Fuco & Pras & Chlb & Allox & Zea & DV-Chla \\
\hline$C_{\mathrm{o}}$ & 0.28 & 0.07 & 0.30 & 0.07 & 0.07 & 0.14 & 0.07 & 0.06 & nd \\
$\mu_{\mathrm{o}}$ & 1.11 & 1.35 & 0.74 & 0.67 & 1.50 & 1.70 & 0.48 & 0.54 & nd \\
$\mu_{\mathrm{n}}$ & 1.36 & 1.47 & 0.95 & 0.95 & 1.63 & 1.58 & 0.56 & 0.68 & nd \\
$m$ & 0.29 & 0.43 & 0.26 & 0.35 & 0.94 & 0.96 & 0.30 & 0.54 & nd \\
$\mu_{\mathrm{o}}: \mu_{\mathrm{n}}$ & 0.82 & 0.92 & 0.78 & 0.71 & 0.92 & 1.08 & 0.86 & 0.78 & nd \\
PP & 0.48 & 0.15 & 0.29 & 0.06 & 0.13 & 0.36 & 0.04 & 0.03 & nd \\
$G$ & 0.13 & 0.05 & 0.10 & 0.03 & 0.08 & 0.20 & 0.02 & 0.03 & nd \\
\hline
\end{tabular}

$* \mu_{\mathrm{o}}=0.01\left(\mathrm{~d}^{-1}\right)$ is assumed for $\mu_{\mathrm{o}}: \mu_{\mathrm{n}}$ and PP estimates nd $=$ no data

$\left(>20^{\circ} \mathrm{C}\right)$ with a stronger vertical gradient and the deeper thermocline in OCT-15 could be associated not only with El Niño 2015-2016 but also with a seasonal cyclonic recirculation of the California Current, mainly in summer, autumn, and winter, when an eastward flow brings oligotrophic ocean waters towards the coast (Linacre et al. 2010b). Thus, smaller planktonic cells that grow efficiently in low-nutrient environments could be carried to nearshore waters (Linacre et al. 2010a). In fact, in OCT-15 the growth of larger cells, such as diatoms $\left(\mu_{\text {o-Fuco }}: \mu_{n-\text { Fuсo }}<1\right)$, was severely limited. Furthermore, norte de Baja California por el programa IMECOCAL (Durazo et al. 2017). Para ABR-16, los perfiles de temperatura y salinidad mostraron aparentemente un retorno de las condiciones propias de primavera en este sistema de surgencia costera, y, aunque en menor grado, esta recuperación también fue evidente hacia zonas más oceánicas de la región norte Baja California.

Bajo este contexto ambiental de variabilidad interanual y, en parte, variabilidad estacional, se observaron durante este estudio notables diferencias en las condiciones hidrográficas. 

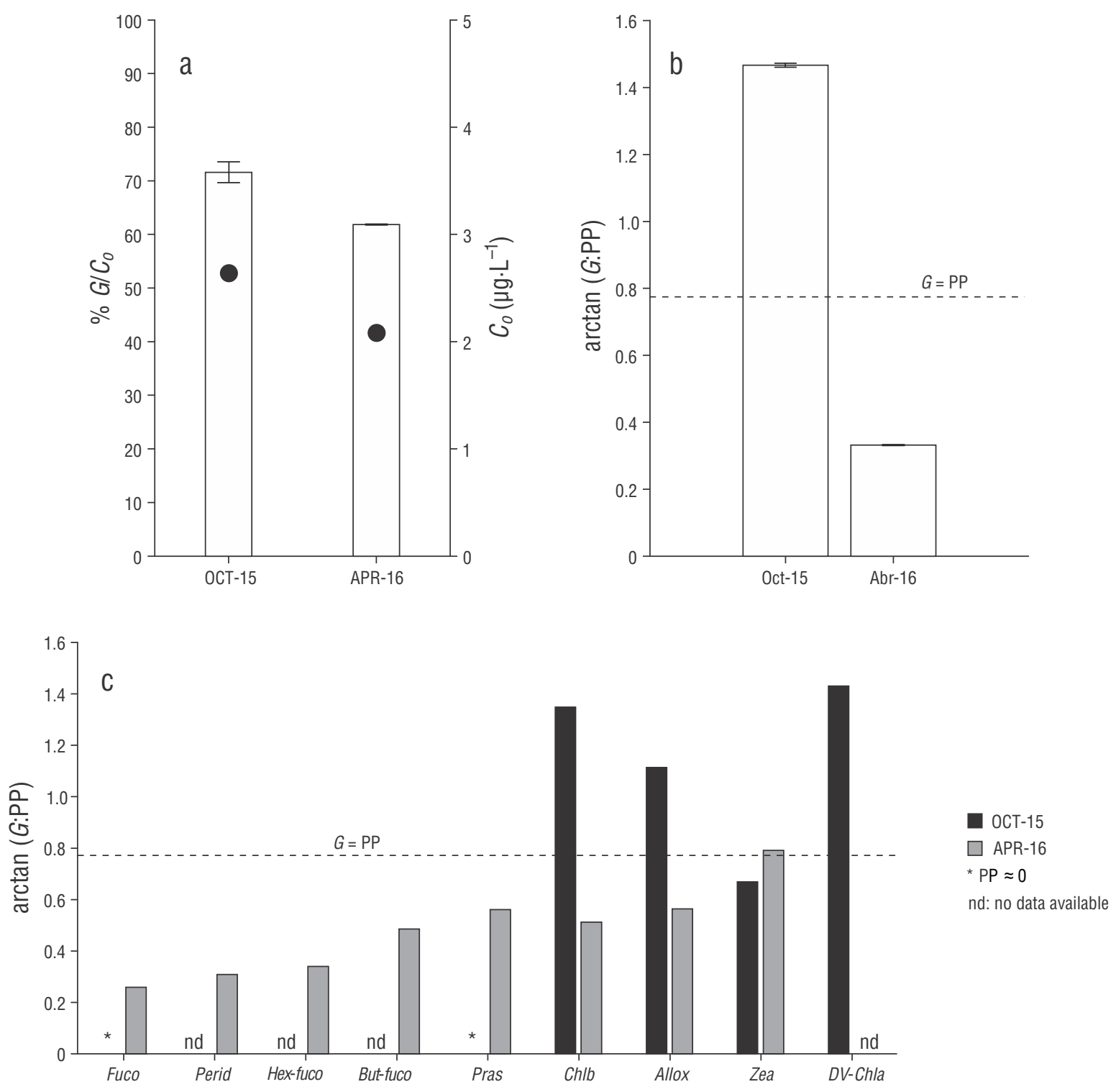

Figure 5. Microzooplankton grazing impact in October 2015 (OCT-15) and April 2016 (APR-16) on (a) phytoplankton biomass (bars, left $y$ axis), estimated as the initial chlorophyll $a$ concentration $\left(C_{\mathrm{o}}\right)$ (filled circles, right $y$ axis); (b) daily primary production (PP) of the phytoplankton community; and (c) daily PP of specific phytoplankton groups associated with specific pigments such as diatoms (fucoxanthin: Fuco), dinoflagellates (peridinin: Perid), prymnesiophytes (19'-hexanoyloxyfucoxanthin: Hex-Fuco), pelagophytes (19'butanoyloxyfucoxanthin: But-Fuco), prasinophytes (prasinoxanthin: Pras), green algae (Chlorophyll b: Chlb), cryptophytes (alloxanthin: Allox), cyanobacteria (Zeaxanthin: Zea), and Prochlorocccus spp. (Divinyl chlorophyll $a$ : DV-Chla). Dashed line indicates $G$ is equal to the PP value

Figura 5. Impacto de pastoreo ejercido por el microzooplancton durante octubre de 2015 (OCT-15) y abril de 2016 (APR-16) sobre (a) la biomasa de fitoplancton (barras, eje $y$ izquierdo), estimada como la concentración inicial $\left(C_{\mathrm{o}}\right)$ de clorofila $a$ (círculos rellenos, eje $y$ derecho); (b) sobre la producción primaria (PP) diaria de la comunidad fitoplanctónica; y (c) sobre la PP diaria de grupos específicos de fitoplancton asociados a ciertos pigmentos accesorios, tales como diatomeas (fucoxantina: Fuco), dinoflagelados (peridinina: Perid), prymnesiofitas (19'hexanoiloxifucoxantina: Hex-Fuco), pelagofitas (19'-butanoiloxifucoxantina: But-Fuco), prasinofitas (prasinoxantina: Pras), algas verdes en general (clorofila $b$ : Chlb), criptofitas (aloxantina: Alox), cianobacterias (zeaxantina: Zea) y Prochlorocccus spp. (divinil clorofila $a$ : DV$C h l a)$. La línea punteada indica un valor del consumo diario por el microzooplancton $(G)$ equivalente a PP. 
dominance of nanoflagellates and picophytoplankton was inferred from the high concentrations of Zea and the presence of $D V$-Chla, which are pigments that are characteristic of Synechococcus and specific for Prochlorococcus, respectively (Fig. 4a, Table 2).

Another factor that probably influenced the temporal contrasts in PP could be related to the trophic response of microplanktonic consumers. Previous studies conducted at the site (Linacre et al. 2012) have shown that, under contrasting oceanographic conditions, there is a complementary coupling of microplankton consumers in terms of community structure (relative abundance, size, and composition) with the seasonal changes of their prey (ranging from bacteria to large diatoms), in response to the trophic dynamics that allows efficient carbon recycling within the euphotic zone. In OCT-15, the increased consumption of prey- mainly nano/picophytoplankton - was seemingly associated with the larger fraction of mixotrophic and heterotrophic dinoflagellates (e.g., Gyrodinium and Gymnodinium) observed at this coastal site during the warmer conditions, which have been described as a major component of microzooplankton and active diatom grazers (Sherr and Sherr 2007). In addition, many of the dinoflagellates previously thought to be exclusively autotrophic have been reclassified as mixotrophic, because they feed on diverse types and sizes of prey, suggesting a new ecological insight by their significant role as phagotrophic in microplankton food webs (Jeong et al. 2010). In APR-16, a lower impact on PP was observed, likely due to the type and size of potential predators (ciliates) and the relative dominance of certain autotrophic prey (diatoms). Although ciliates have been reported as active microplankton consumers of whole chains and solitary diatom cells in coastal systems (Aberle et al. 2007, Teixeira et al. 2011, Linacre et al. 2012), the relative abundance of this group (average $\sim 60 \%$ ) or the size of its components (nanoplankton) in APR-16 were likely not important enough to significantly limit the dominant diatom group. This is suggested by the minor grazing impact on diatom PP, unlike the greater grazing pressure on cyanobacteria during both seasons (Fig. 5c). The large loss rate of picoplankton cells observed in this study seems to be a trophic pattern that occurs throughout the year in coastal upwelling ecosystems (Linacre et al. 2010a, Teixeira et al. 2011).

The effects of the anomalous warming period from 2014 to early 2016 on the CCS pelagic ecosystem have already been evidenced by the decrease in biomass and PP, especially in coastal areas (McClatchie et al. 2016, Gómez-Ocampo et al. 2017). Apparently, these effects were also reflected in the ENSENADA station, as indicated by the 2- to 30-fold decrease in the abundance of nano- and microphytoplankton relative to previous records for 2007-2008 (data not published) and by the growth and mortality dynamics controlled by microzooplankton grazing (Table 1). In this regard, Table 1 shows a comparison of the experimental rates observed during this study (OCT-15 and APR-16) and those estimated from previous cruises in autumn
Estas diferencias influyeron posiblemente en la disponibilidad de nutrientes para el fitoplancton dentro de la zona eufótica (McClatchie et al. 2016, Zaba y Rudnick 2016), generando así los marcados contrastes observados entre OCT-15 y ABR-16 en las tasas de crecimiento $(\mu)$ de fitoplancton y, consecuentemente, la PP diaria de la comunidad (basada en Chla) y de ciertos grupos autotróficos (basada en pigmentos específicos). Aunque este estudio carece de información sobre las concentraciones de nutrientes, al revisar como referencia los valores de nitrato en la capa de mezcla en el SCC que han sido reportados para la región de CalCOFI, en promedio, los valores fueron bajos durante 2015-2016 y la nutriclina fue inusualmente más profunda comparada con los 15 años previos, debido a una fuerte estratificación en los primeros $100 \mathrm{~m}$ de la columna de agua (McClatchie et al. 2016). La baja disponibilidad de nutrientes inorgánicos en el SCC, generó en consecuencia bajas concentraciones de Chla durante 2015, debido a surgencias moderadas y a las condiciones de El Niño 2015-2016, sobre todo en la zona costera de la región sur de California. Además, para la región norte de IMECOCAL, que está cercana al área de estudio, se reportaron anomalías negativas de Chla integrada en los primeros $100 \mathrm{~m}$ durante otoño de 2015. Para abril de 2016, las concentraciones de Chla aparentemente regresaron a valores cercanos al promedio climatológico (McClatchie et al. 2016). En concordancia con estos antecedentes, las bajas temperaturas $\left(<14^{\circ} \mathrm{C}\right)$ registradas en la zona eufótica de la zona de estudio durante ABR-16 podrían estar indicando un ascenso de aguas subsuperficiales frías y ricas en nutrientes por eventos de surgencia, una vez que el sistema retornó a sus condiciones normales (Durazo et al. 2017). La dominancia de diatomeas en ABR-16 podría ser un indicador de este enriquecimiento de nutrientes por surgencias, dado que la turbulencia vertical incrementa la proporción de células más grandes dentro de la capa iluminada (Rodriguez et al. 2001, Linacre et al. 2012). En comparación, las mayores temperaturas superficiales $\left(>20^{\circ} \mathrm{C}\right)$, el mayor gradiente vertical y la termoclina más profunda durante OCT-15 podrían deberse no sólo al evento de El Niño 2015-2016, sino además a que estacionalmente, principalmente durante verano, otoño e invierno, hay un mayor aporte hacia la costa de aguas oceánicas y oligotróficas por recirculación ciclónica de la corriente de California (Linacre et al. 2010b), las cuales estarían acarreando células fitoplanctónicas más pequeñas que crecen eficientemente en ambientes de bajos nutrientes (Linacre et al. 2010a). En efecto, durante OCT-15 se observó una fuerte limitación en el crecimiento de células de mayor tamaño como diatomeas $\left(\mu_{\mathrm{o}-\text { Fuco }}: \mu_{\mathrm{n}-\text {-Fuco }}<1\right)$. Además, se registró una dominancia de células nanoflageladas y de picofitoplancton, de acuerdo con las altas concentraciones del pigmento Zea y la presencia del pigmento DV-Chla, característico y específico de Synechococcus y Prochlorococcus, respectivamente (Fig. 4a, Tabla 2).

Otro aspecto que estaría determinando las diferencias temporales de la PP podría relacionarse con la respuesta 
(NOV-07-NOV-08) and spring (APR-08) at the same coastal site. Although OCT-15 yielded the highest phytoplankton biomass of the 3 autumns, $\mu_{\mathrm{o}}$ values are $\sim 2-4$ times lower, $\mu_{\mathrm{n}}$ $\sim 1.5-3$ times higher, and $m \sim 2-9$ times higher than estimates for autumn 2007 and autumn 2008 (Table 1). In APR-16, when a lower initial Chla value was observed, the low $\mu_{\mathrm{o}}$ and $\mu_{\mathrm{n}}$ rates were almost 2 -fold and $m$ was similar to the values recorded in spring 2008, a typical year of the cold conditions of La Niña 2007-2008.

The results of this study indicate that the effects of the sequence of warm events ("The warm Blob" 2013-2015 and El Niño 2015-2016) in this CCS coastal region were most evident in OCT-15, when growth of the phytoplankton community, particularly the growth of larger components such as diatoms, was severely restricted. This occurred not only because of the limitation of nutrients caused by the increased supply of warm water and the sinking of the thermocline/ nutricline, but also because of the strong impact of microzooplankton grazing, which actively consumed phytoplankton biomass $(72 \%)$ and PP (>100\%), even when a greater seasonal grazing impact was expected in autumn (e.g., NOV-08, Table 1). The maximum PP value recorded in APR-16, compared to other seasons (Table 1), could reflect the environmental recovery of this coastal ecosystem during the spring of 2016 .

\section{ACKNOWLEDGMENTS}

This study was funded by the National Council for Science and Technology (Mexico, project no. CB-201101167361). LL, JRLL, and RD are recipients of a grant from the Sistema Nacional de Investigadores. The authors would like to thank the students, technicians, and scientists who directly and indirectly assisted in the generation of data for this study. The authors are particularly grateful to Martín de la Cruz-Orozco (CICESE) for his valuable collaboration in correcting the systematic bias of chlorophyll $a$ data at the lab. Thanks are also due to the captain and crew of the R/V Alpha Helix for their valuable assistance at sea. The FICOTOX Laboratory at CICESE provided the HPLC analyses, and Yaireb Sánchez-Bravo (CICESE) performed the taxonomic analysis of phytoplankton. This article was translated to English by María Elena Sánchez. We wish to thank the 3 anonymous reviewers for their valuable comments, which undoubtedly led to improve the quality of this article.

\section{REFERENCES}

Aberle N, Lengfellner K, Sommer U. 2007. Spring bloom succession, grazing impact and herbivore selectivity of ciliate communities in response to winter warming. Oecologia 150: 668-681.

Almazán-Becerril A, García-Mendoza E. 2008. Maximum efficiency of charge separation of the photosystem II of the phytoplankton community in the Eastern Tropical North Pacific off Mexico: A nutrient stress diagnostic tool? = La eficiencia cuántica máxima de separación de carga del fotosistema II de la trófica de los consumidores microplanctónicos. Estudios previos en la estación ENSENADA (Linacre et al. 2012) han demostrado que bajo condiciones oceanográficas contrastantes, existe un acoplamiento complementario de los consumidores microplanctónicos en cuanto a su estructura comunitaria (abundancia relativa, tamaño y composición) con los cambios estacionales de sus presas (desde bacterias hasta grandes diatomeas), respondiendo a una dinámica trófica que permite el eficiente reciclamiento del carbono dentro de la zona eufótica. Durante OCT-15 el mayor consumo de presas, principalmente nano- y picofitoplanctónicas, estuvo aparentemente asociado a la mayor fracción de dinoflagelados mixotróficos y heterotróficos (e.g., Gyrodinium y Gymnodinium) presentes durante las condiciones más cálidas de este sitio costero, los cuales han sido descritos como un componente significativo del microzooplancton y activos pastoreadores de diatomeas (Sherr y Sherr 2007). Incluso, se ha demostrado que muchos de los dinoflagelados que se creían exclusivamente fototróficos han sido recategorizados como mixotróficos debido al consumo de presas muy variadas y, por tanto, han recibido un nuevo enfoque ecológico por su papel significativo como fagotróficos dentro de las tramas tróficas microplanctónicas (Jeong et al. 2010). Durante ABR-16, en cambio, se observó un menor impacto sobre la PP, posiblemente debido a una combinación entre el tipo y tamaño de predadores potenciales (ciliados) y la dominancia relativa de ciertas presas autotróficas (diatomeas). Aunque se ha reportado a los ciliados como activos consumidores microplanctónicos de cadenas completas y células solitarias de diatomeas en sistemas costeros (Aberle et al. 2007, Teixeira et al. 2011, Linacre et al. 2012), es posible que durante ABR-16 la abundancia relativa de este grupo (promedio $\sim 60 \%$ ) o el tamaño de sus componentes (nanoplanctónicos) no fueron lo suficientemente importantes como para impactar significativamente al dominante grupo de diatomeas. Esto es sugerido por el menor impacto ejercido sobre su PP, en contraste con la mayor presión de pastoreo ejercida sobre las cianobacterias durante ambos periodos (Fig. 5c). La mayor pérdida de células picoplanctónicas en este estudio parece ser un patrón trófico que es permanente todo el año en ecosistemas de surgencia costera (Linacre et al. 2010a, Teixeira et al. 2011).

Los efectos del calentamiento anómalo desde 2014 hasta principios de 2016 sobre el ecosistema pelágico del SCC, ya han sido evidenciados en la disminución de la biomasa y PP, sobre todo en la porción costera (McClatchie et al. 2016, Gómez-Ocampo et al. 2017). Aparentemente, estos efectos también se reflejaron en la estación ENSENADA, a través de un decremento en la abundancia de nano- y microfitoplancton de 2 hasta 30 veces, en comparación con registros previos de 2007-2008 (datos no publicados) y aparentemente también, en su dinámica de crecimiento y mortalidad por consumo del microzooplancton (Tabla 1). Al respecto, la Tabla 1 muestra una comparación de las tasas experimentales de este 
comunidad de fitoplancton en el Pacífico Nororiental Tropical Mexicano: ¿Una herramienta adecuada para diagnosticar el estrés por nutrientes? Cienc. Mar. 34(1): 29-43.

Calbet A, Landry M. 2004. Phytoplankton growth, microzooplankton grazing, and carbon cycling in marine systems. Limnol. Oceanogr. 49(1): 51-57.

Calbet A, Trepat I, Almeda R, Saló V, Saiz E, Movilla JI, Alcaraz M, Yebra L, Simó R. 2008. Impact of micro- and nanograzers on phytoplankton assessed by standard and size-fractionated dilution grazing experiments. Aquat. Microb. Ecol. 50: $145-156$.

http://dx.doi.org/10.3354/ame01171

Cavole L, Demko A, Diner R, Giddings A, Koester I, Pagniello C, Paulsen M, Ramirez-Valdez A, Schwenck S, Yen N, Zill M, Franks P. 2016. Biological impacts of the 2013-2015 warmwater anomaly in the Northeast Pacific: Winners, losers, and the future. Oceanogr. 29(2): 273-285.

Chisholm S. 2000. Oceanography: Stirring times in the Southern Ocean. Nature 407: 685-687.

Durazo R, Castro R, Miranda LE, Delgadillo-Hinojosa F, MejíaTrejo A. 2017. Condiciones hidrográficas anómalas frente al noroeste de la península de Baja California durante 2014-2016. Cienc. Mar. 43(2): 81-92.

Gómez-Ocampo E, Gaxiola-Castro G, Durazo R, Beier E. 2017. Effects of the 2013-2016 warm anomalies on the California Current phytoplankton. Deep-Sea Res. II. http://dx.doi.org/10.1016/j.dsr2.2017.01.005

Jacox MG, Hazen EL, Zaba KD, Rudnick DL, Edwards CA, Moore AM, Bograd SJ. 2016. Impacts of the 2015-2016 El Niño on the California Current System: Early assessment and comparison to past events. Geophys. Res. Lett. 43(13): 7072-7080. http://dx.doi.org/10.1002/2016GL069716

Jeong HJ, Yoo YD, Kim JS, Seong KA, Kang NS, Kim TH. 2010. Growth, feeding and ecological roles of the mixotrophic and heterotrophic dinoflagellates in marine planktonic food webs. Ocean. Sci. J. 45(2): 65-91. http://dx.doi.org/10.1007/s12601-010-0007-2

Landry M, Hassett R. 1982. Estimating the grazing impact of marine microzooplankton. Mar. Biol. 67: 283-288.

Linacre LP, Landry MR, Lara-Lara R, Hernández-Ayón JM, BazánGuzmán C. 2010a. Picoplankton dynamics during contrasting seasonal oceanographic conditions at a coastal upwelling station off Northern Baja California, México. J. Plankton Res. 32(4): $539-557$. https://doi.org/10.1093/plankt/fbp148

Linacre L, Durazo R, Hernández-Ayón JM, Delgadillo-Hinojosa F, Cervantes-Díaz G, Lara-Lara JR, Camacho-Ibar V, SiqueirosValencia A, Bazán-Guzmán C. 2010b. Temporal variability of the physical and chemical water characteristics at a coastal monitoring observatory: Station ENSENADA. Cont. Shelf Res. 30(16): 1730-1742. https://doi.org/10.1016/j.csr.2010.07.011

Linacre L, Landry MR, Cajal-Medrano R, Lara-Lara JR, Hernández-Ayón JM, Mouriño-Pérez RR, García-Mendoza E, Bazán-Guzmán C. 2012. Temporal dynamics of carbon flow through the microbial plankton community in a coastal upwelling system off northern Baja California, México. Mar. Ecol. Prog. Ser. 461: 31-46.

http://dx.doi.org/10.3354/meps09782

McClathchie S, Goericke R, Leising A, Auth T, Bjorkstedt E, Robertson R, Brodeur R, Du X, Daly E, Morgan C, et al. 2016. State of the California Current 2015-16: Comparisons with the 1997-98 El Niño. CalCOFI Rep. 57: 5-61. estudio (OCT-15 y ABR-16) con aquellas obtenidas en cruceros previos de otoño (NOV-07 a NOV-08) y primavera (ABR-08) en la estación ENSENADA. Aunque OCT-15 tiene la mayor biomasa fitoplanctónica de los 3 otoños, los valores de $\mu_{\mathrm{o}}$ son $\sim 2-4$ veces menor, $\mu_{\mathrm{n}} \sim 1.5-3$ veces mayor y $m \sim 2-9$ veces mayor que los valores estimados en otoño de 2007 y 2008 (Tabla 1). En ABR-16, cuando los valores de Chla inicial fueron menores, las tasas $\mu_{\mathrm{o}} \mathrm{y} \mu_{\mathrm{n}}$ fueron casi el doble y $m$ fue similar al valor obtenido en la primavera de 2008, un año típico de condiciones frías de La Niña 2007-2008.

Los resultados de este estudio indican que los efectos de la secuencia de eventos cálidos en esta región costera del SCC ("The warm Blob” y El Niño 2015-016) fueron más evidentes durante OCT-15, época en que la comunidad de fitoplancton, en especial los componentes más grandes como diatomeas, estuvo fuertemente restringida en su crecimiento. Esto ocurrió no sólo por una limitación ambiental de nutrientes ocasionado por el mayor aporte de agua cálida a la zona y un hundimiento de la termoclina y la nutriclina, sino además por un fuerte impacto de pastoreo del microzooplancton, el cual consumió activamente la biomasa fitoplanctónica (72\%) y la PP generada diariamente $(>100 \%)$, aún cuando estacionalmente se esperaba un mayor impacto de pastoreo en otoño (e.g., NOV-08, Tabla 1). De igual forma, la máxima PP registrada en ABR-16 en comparación con otras épocas (Tabla 1) pudo ser el reflejo de la recuperación ambiental de este ecosistema costero durante la primavera de 2016.

\section{Agradecimientos}

Este trabajo fue financiado por el Consejo Nacional de Ciencia y Tecnología (México, no. de proyecto CB-201101167361). LL, JRLL y RD son receptores de la beca del Sistema Nacional de Investigadores. Los autores agradecemos a los estudiantes, técnicos y científicos que ayudaron directa e indirectamente a la generación de los datos de este trabajo y, en particular, a Martín de la Cruz-Orozco (CICESE) su gran colaboración en el laboratorio y en la corrección del sesgo sistemático de los datos de clorofila $a$. Agradecemos, además, al capitán y a la tripulación del $\mathrm{B} / \mathrm{O}$ Alpha Helix su valiosa ayuda en el mar. El Laboratorio FICOTOX de CICESE procesó los análisis de HPLC, y Yaireb Sánchez-Bravo (CICESE) realizó los análisis taxonómicos del fitoplancton. Este artículo fue traducido al inglés por María Elena Sánchez. Finalmente, los autores agradecen a los 3 revisores anónimos sus valiosos comentarios que, sin lugar a dudas, permitieron mejorar la calidad de este artículo. 
Omura T, Iwataki M, Borja VM, Takayama H, Fukuyo Y. 2013. Marine phytoplankton of the Western Pacific. Tokyo, Kouseisha Kouseikaku, Japan, 160 pp.

Rodríguez J, Tintoré J, Allen JT, Blanco JM, Gomis D, Reul A, Ruiz J, Rodriguez V, Echevarría F, Jiménez-Gómez F. 2001. Mesoscale vertical motion and the size structure of phytoplankton in the ocean. Nature 410: 360-363.

Sherr EB, Sherr BF. 2007. Heterotrophic dinoflagellates: a significant component of microzooplankton biomass and major grazers of diatoms in the sea. Mar. Ecol. Prog. Ser. 352: 187-197.

Teixeira I, Figueiras F, Crespo B, Piedracoba S. 2011. Microzooplankton feeding impact in a coastal upwelling system on the NW Iberian margin: the Ría de Vigo. Estuar. Coast. Shelf. Sci. 91(1): 110-120. https://doi.org/10.1016/j.ecss.2010.10.012

Throndsen J. 1978. Preservation and storage. In: Sournia A (ed.), Monographs on Oceanographic Methodology. No. 6. Phytoplankton Manual. United Nations Educational, Scientific and Cultural Organization (UNESCO), Paris. 69-74 pp.
Tomas C. 1997. Identifying Marine Phytoplankton. Academic Press, New York (NY), 858pp.

Utermöhl VH. 1931. Neue Wege in der quantitativen Erfassung des Planktons. Verh. Int. Verein. Theor. Angew. Limnol. 5: 567-596.

Vargas CA, Martínez RA, Cuevas LA, Pavez MA, Cartes C, González HE, Escribano R, Giovanni D. 2007. The relative importance of microbial and classical food webs in a highly productive coastal upwelling area. Limnol. Oceanogr. 52(4): $1495-1510$.

http://dx.doi.org/ 10.4319/lo.2007.52.4.1495

Welschmeyer N. 1994. Fluorometric analysis of chlorophyll $a$ in the presence of chlorophyll $b$ and pheopigments. Limnol. Oceanogr. 39(8): 1985-1992. http://dx.doi.org/ 10.4319/lo.1994.39.8.1985

Zaba KD, Rudnick DL. 2016. The 2014-2015 warming anomaly in the Southern California Current System observed by underwater gliders. Geophys. Res. Lett. 43(3): 1241-1248.

Received March 2017, accepted May 2017. 